\title{
Micromorphological evidence for multiphase sedimentation and deformation during overpressurised fluid flow associated with hydrofracturing
}

\section{EMRYS PHILLIPS, JEZ EVEREST AND HELEN REEVES}

Phillips, E., Everest, J. \& Reeves, H. Micromorphological evidence for multiphase sedimentation and deformation during hydrofracturing

Keywords: micromorphology, hydrofractures, subglacial to ice marginal environments

Hydrofracture systems are being increasingly recognised within subglacial to ice marginal settings and represent a visible expression of the passage of pressurised meltwater through these glacial environments. Such structures provide a clear record of fluctuating hydrostatic pressure, leading to brittle fracturing of the host sediment/bedrock, and penecontemporaneous liquefaction and introduction of the sediment-fill. A detailed macro and microstructural study of a hydrofracture system cutting Devonian sandstone bedrock exposed at the Meads of St. John, near Inverness (NE Scotland) has revealed that this complex multiphase system was active over a prolonged period and accommodated several phases of fluid flow. The main conduits which fed the hydrofracture system are located along bedding within the sandstone, with the site of the wider, steeply inclined to subvertical, transgressive linking sections being controlled by the contemporaneous development of high-angle fractures and normal faults; the latter occurring in response to localised extension within the bedrock. A comparison with published engineering hydraulic fracturing data indicates that the various stages of sediment-fill deposited during a flow event can be directly related to the fluctuation in overpressure during hydrofracing. A model is proposed linking the evolution of this hydrofracture system to the retreat of the overlying Findhorn glacier. The results of this study also indicate that the development and repeated reactivation of subglacial hydrofracture systems can have a dramatic effect on the permeability of the bed, influencing the potential for overpressure build-up within the subglacial hydrogeological system, and facilitating the migration of meltwater beneath glaciers and ice sheets.

Emrys Phillips (erp@bgs.ac.uk; British Geological Survey, Murchison House, West Mains Road, Edinburgh EH9 3LA, UK); Jez Everest (British Geological Survey, Murchison House, West Mains Road, Edinburgh EH9 3LA, UK); Helen Reeves (British Geological Survey, Sir Kingsley Dunham Centre, Nicker Hill, Keyworth, Nottingham NG12 5GG, UK)

Hydrofracture systems, also referred to as water-escape features or clastic dykes, represent a visible expression of the passage of pressurised meltwater through subglacial to ice marginal environments (Dionne \& Shilts 1974; Christiansen et al. 1982; von Brunn \& Talbot 1986; Burbridge et al. 1988; Dreimanis 1992; Larsen \& Mangerud 1992; McCabe \& Dardis 1994; Dreimanis \& Rappol 1997; van der Meer et 
al. 1999; Rijsdijk et al. 1999; Le Heron \& Etienne 2005; Boulton 2006; Goździk \& van Loon 2007; van der Meer et al. 2008; Phillips \& Merritt 2008). Previous work has demonstrated that hydrofractures record marked fluctuations in hydrostatic pressure within the glacial hydrogeological system, leading to brittle fracturing of the preexisting sediment and/or bedrock, and the penecontemporaneous liquefaction and introduction of a sediment-fill (see van der Meer et al. 2008 and references therein). Depending on the consolidation of the host sediment or bedrock, closed fractures or joints may already exist prior to hydrofracturing, with the elevated hydrostatic pressures leading to the reactivation of these pre-existing structures. However, brittle fracturing may also be initiated by these "high pressure events" with the contemporaneous introduction of the sediment-fill being described by Larsen \& Mangerud (1992) as "cut-and-fill". Due to the pressurised nature of the meltwater, the infill can be introduced from structurally above (downward injection) or below (upward injection) the developing hydrofracture system (Dreimanis 1992; Rijsdijk et al. 1999; Le Heron \& Etienne 2005; Goździk \& van Loon 2007; van der Meer et al. 2008). Furthermore, it is becoming increasingly apparent that the introduction of pressurised meltwater can have a profound effect on subglacial to ice-marginal deformation, for example aiding in the development of water-lubricated detachments within the sediment pile (e.g. Phillips et al. 2002; Benediktsson et al. 2008) which can promote rapid ice movement (e.g. Kjær et al. 2006). Hydrofracturing may also facilitate the initial detachment and transport of sediment and/or bedrock rafts (e.g. Moran et al. 1980; Broster 1991; Broster \& Seaman 1991; Benn \& Evans 1998; Phillips \& Merritt 2008; Burke et al. 2008).

This paper presents the results of a detailed study of a complex hydrofracture system cutting Middle to Upper Devonian sandstone bedrock exposed at the Meads of St. John, near Inverness, northeast Scotland. The study area is located at the confluence of ice flowing down the Findhorn valley with the main trunk of the Moray Firth Ice Stream (Fig. 1), with the hydrofracture system providing an insight into the subglacial palaeo-hydrology beneath this part of the British and Irish Ice Sheet. The key objective of this study was to investigate the history of 'flow events' recorded by this complex multiphase hydrofracture system using macroscopic structural and sedimentological field based evidence, coupled with micromorphological analysis. The results were then compared with published engineering hydraulic fracturing ('fracking') data to provide a basis on which to relate the various stages of sedimentfill to the fluctuation in internal fluid overpressure during hydrofracturing. This comparison has provided a insight into the overpressures required to repeatedly reactivate hydrofracture systems as they accommodate subsequent flow events. The findings of this study have been used to show that the development and repeated reactivation of subglacial hydrofracture systems can have a dramatic effect on the permeability of the bed, influencing the potential for overpressure build-up within the subglacial hydrogeological system, and facilitating the migration of meltwater beneath glaciers and ice sheets.

\section{Geological setting}

The Meads of St. John (Fig. 1) are located immediately to the west of the River Findhorn where the Findhorn valley ends and the river continues flowing northward across the low-relief Morayshire coastal plain. The site occurs close to a major geomorphological, stratigraphical and glaciological boundary. To the north and east of the site, the coastal plain is dominated by the floodplain and deposits of the River 
Findhorn, as well as raised marine deposits relating to higher relative sea level stands during the Devensian Late Glacial Maximum (Firth 1990). In contrast, to the south, is a complex terrain comprising glacial, glaciofluvial and ice marginal landforms and deposits, largely underlain by till resting on bedrock. At the Meads of St. John, the bedrock comprises well-bedded, fluviatile calcareous sandstones, siltstones and conglomerates of the Middle to Upper Devonian Kingsteps Sandstone Formation of the Forres Sandstone Group (Fig. 2A). The bedrock is overlain by $1.5 \mathrm{~m}$ of redbrown, sandy gravelly diamicton rich in locally derived sandstone fragments. The till is in turn overlain by a $\sim 2 \mathrm{~m}$ thick unit of coarsely bedded, medium-grade, pebbly gravel, interpreted as a glaciofluvial deltaic deposit.

The Devensian (Weichselian) glacial history of the Meads of St. John area is complex, and is yet to be fully resolved. However, the broader scale geomorphology of the region suggests that the site occurs close to the confluence of ice flowing northward down the Findhorn valley, with the northeasterly flowing Moray Firth Ice Stream (MFIS) (Fig. 1). This ice stream was sourced in the western Scottish Highlands and flowed into the Moray Firth via the Great Glen, eventually invading the coastal lowlands of Moray, Banffshire and Buchan (Merritt et al. 2003). The MFIS is one of a number of relatively faster flowing corridors of ice which are thought to have regulated the size and shape of the British and Irish Ice Sheet (BIIS) during the Devensian (see Merritt et al. 1995; Knight et al. 1999; Ó Cofaigh \& Evans 2001; Scourse \& Furze 2001; Evans \& Ó Cofaigh 2003; Jansson \& Glasser 2005; Everest et al. 2005; Golledge \& Stoker 2006; Roberts et al. 2007; Davidson \& Stoker 2007; Bradwell et al. 2007; Evans et al. 2009).

Ice flowing down the Findhorn valley eventually separated from the MFIS and retreated southwards towards the northern end of the Monadhliadh Mountains. The timing of this separation is at present unknown. However, the presence of several sequences of ice-dammed lake deposits on top of terraces within the Findhorn valley indicate that this process took place over a prolonged period. The ice dam was probably formed by the MFIS which blocked the ice from the Findhorn valley. The subsequent deglaciation in this part of the Moray Firth is dominated by two clearly identifiable stages. The first, indicated by parallel NE-SW aligned features along the higher ground to the south of the coastal plain, record the progressive thinning of the MFIS lateral margin, while its terminus still lay some way to the northeast. At the start of the second stage a threshold was crossed, approximately at the time when the lateral margin lay close to the Meads of St. John, whereby the MFIS became topographically confined and accelerated terminal retreat occurred, prior to the final deglaciation of the area.

On a local scale, the landforms in the area around the Meads of St. John are dominated by southwest to northeast-trending positive and negative features. Relict subglacial, and most likely sub-marginal drainage pathways are clearly visible along the northwestern flanks of the higher ground which extends south of the site towards the Monadhliadh Mountains. To the northeast and southwest of the site, several sets of ice-marginal ridges are aligned sub-parallel to and help define the lateral margin of the ice occupying the Moray Firth. These ridges are largely composed of poorly sorted sub-rounded medium gravels and sandy gravelly diamictons, interpreted as composite glaciofluvial ice-marginal and morainic deposits. Between these ridges areas of glacial outwash are relatively common, all indicating dominant subaerial meltwater flow from southwest to northeast. Sequential thinning of MFIS is shown by parallel sets of ridges and meltwater features descending to the coastal plain, where raised marine deposits dominate the stratigraphy. A zone of transition occurs broadly 
across and to the north of the Meads of St. John site, where evidence of ice marginal thinning is replaced by more dominant and most likely more rapid terminal retreat.

\section{Methodology}

Prior to sampling, the Meads of St. John hydrofracture system was logged, photographed and described in detail (see Fig. 2C, D), with particular emphasis being placed on recording the dip and strike of bedding and pre-existing joints within the sandstone bedrock, as well as the geometry, orientation and inter-relationships between the various components of this complex system of sediment filled veins. A total of ten intact block samples (N12282 to N12291; Fig. 2D) of the sediment-fill and adjacent bedrock were taken using $10 \mathrm{~cm}$ cubed, aluminium Kubiena tins. The tins were either cut (using a plaster board/rock hand saw) or pushed into the face in order to limit sample disturbance. The position of the sample within the hydrofracture system, its orientation relative to magnetic north, depth and way-up were marked on the outside of the tin during collection. The samples were collected at different locations within the hydrofracture system to provide detailed information on its internal architecture and range of structures developed at various points within this complex network of features. A sequence of overlapping photographs were then taken of the Kubiena tins embedded in the face (see Fig. 2D) to provide a visual record of the location of the individual samples and their context with respect to the main bedding-parallel feeder conduits and more steeply inclined, cross-cutting sections of the hydrofracture system. Each sample was then removed from the face, sealed in two plastic bags, and stored in a cold store to prevent the material from drying out prior to sample preparation.

Sample preparation (total time $\sim 10$ months) involved the initial replacement of pore-water by acetone, which was then progressively replaced by a resin and allowed to cure. Large format orientated thin sections were taken from the centre of each of the prepared samples, thus avoiding artefacts associated with sample collection. Each thin section was cut orthogonal to the hydrofracture/vein margin evident from the field investigation. The thin sections were examined using a standard Zeiss petrological microscope and Zeiss projector, the latter allowing detailed study of the range of microstructures at very low magnification. The terminology used to describe the various microtextures developed within these sediments in general follows that proposed by van der Meer (1987, 1993, 1996) and Menzies (2000).

\section{Macro-scale description and interpretation of the Meads of St. John hydrofracture system}

The laterally extensive (50 to $60 \mathrm{~m}$ ) hydrofracture system exposed at the Meads of St. John occurs entirely within the well-bedded sandstones and siltstones of the Kingsteps Sandstone Formation. The bedrock is directly overlain by a poorly exposed sandy diamicton rich in locally derived sandstone rock fragments. No hydrofractures were observed penetrating downwards from, or cutting upwards through this diamicton, with the exposed system occurring entirely within the bedrock. The Meads of St. John site is located near to the mouth of the Findhorn valley, consistent with hydrofracturing having occurred close to the margin of the ice flowing down the Findhorn (i.e. towards the north), possibly as it decoupled from the MFIS and begun to retreat southwards. The hydrofracture system comprises a complex network of locally cross-cutting, sediment-filled veins which range from $1 \mathrm{~cm}$ to over $15 \mathrm{~cm}$ thick (Fig. 2, 3). The margins of the hydrofractures are typically sharp. However, where a hydrofracture cuts an earlier formed sediment-filled vein its margins are 
locally erosive to gradational over 2 to $10 \mathrm{~mm}$. The system comprises two prominent, gently northerly (down-ice) dipping (Fig. 4A), bedding-parallel conduits, or sills, linked and locally cross-cut by a number of typically wider, steeply inclined to subvertical dykes (Fig. 4A) which clearly cross-cut, or transgress, bedding within the bedrock (Fig. 3). The result is a step-like morphology to the hydrofracture system which appears to 'climb' towards the north; i.e. in the direction of ice movement. A similar stepped morphology to sediment filled subglacial/ice marginal hydrofractures has been describe by van der Meer et al. (1999) and van der Meer et al. (2008) from the forefield of Slettjökull (Iceland), and Kumpulainen (1994), associated with a large (125 m long) hydrofracture system exposed to the northeast of Myvatn (Iceland).

In detail, the dykes and sills of the Meads of St. John hydrofracture system are all filled by a similar sequence of finely laminated sand, silt and clay (see Fig. 2B, C). This laminated sediment-fill is crudely zoned from relatively clay- to silt-rich at the margins, becoming progressively sandier and more thickly laminated towards the centre of the hydrofracture. Sediment packages comprising several laminae can be traced laterally for up to $1 \mathrm{~m}$. However, individual laminae maybe lenticular in form and can only be traced for a few tens of centimetres; probably as a result of erosion during a later phase of fluid flow along the hydrofracture system. The dyke-like sections clearly cross-cut each other (Fig. 2B, C), indicating that they were formed at different times and record the progressive development of the Meads of St. John hydrofracture system. Macroscopically the lamination within these connecting dykes occurs parallel to its margin (Fig. 2B, C). The relationships between the dykes on Fig. 2C (labelled 2, 3 and 4) indicate that the focus or site hydrofracture fracturing progressively shifted between each phase of emplacement or 'flow event', in this case, towards the southeast; i.e. in an up-ice direction. This 'shift' may indicate that the earlier dykes effectively became 'sealed' or choked with sediment, forcing subsequent flow event to be diverted, creating/finding a new route through the hydrofracture system. Kumpulainen (1994) noted a similar relationship within the Myvatn hydrofracture system, concluding that only one of the steeply inclined connecting dykes were active at anyone time. Both the bedding-parallel sills and steeply inclined dykes within the Meads of St. John hydrofracture system were later cross-cut by a number of irregular, subvertical fissures filled by a less structured (disrupted) to more massive sand, silt and clay (Fig. 2B, 3).

The bedding-parallel conduits are laterally extensive and can be traced over several tens of metres and probably formed the main feeders to the hydrofracture system, with the upper sill occurring at the base of a distinctive thinly laminated sandstone bed ( $\sim 15 \mathrm{~cm}$ thick; Fig. 3$)$. The dark red colouration of this laminated sandstone is consistent with it possessing a relatively higher modal proportion of a hematitic cement. This highly cemented unit would have formed an impermeable layer within the bedrock helping to focus fluid flow parallel to bedding.

Adjacent to the dykes the bedrock is deformed by a number of high-angle fractures and small-scale normal (extensional) faults that are sub-parallel to the margins of the sediment-filled veins. The faults downthrow to the southeast and record a displacement of between 1 and $5 \mathrm{~cm}$. Similarly orientated normal faults were also identified deforming the sediment within the hydrofractures, indicating that extension and small-scale brittle faulting accompanied the fracturing. Dip and dipdirection data obtained from the dyke and sill-like sections of the Meads of St. John hydrofracture system, and bedding and joints from a nearby outcrop of sandstone bedrock unaffected by hydrofracturing are shown on Fig. 4. Data obtained for both the sills and bedding plot together, consistent with the sill-like feeders to the 
hydrofracture system having exploited this pre-existing bedrock structure. However, data obtained for the dyke-like sections of the hydrofracture are more variable; in marked contrast to the tight cluster formed by the data from the bedrock joints (compare Fig. 4A, B). This evidence indicates that the dyke-like sections of the hydrofracture did not exploit pre-existing joints within the bedrock, but developed in response to contemporaneous fracturing of the sandstone as a result of the fluid overpressures exceeding the tensile strength of the host rock.

The complex cross-cutting relationships displayed between the different parts of the hydrofracture system (Fig. 2B, C, D, 3) clearly demonstrates that this network of sediment-filled dykes and sills developed as a result of several, repeated phases of hydrofracturing and fluid flow.

\section{Micromorphology of the Meads of St. John hydrofracture system}

Thin sections (N12282 to N12291) obtained from different parts of the Meads of St. John hydrofracture system were examined in detail allowing the pattern of sedimentfill and deformation associated with the development of this complex system to be established. The resultant 'microstructural maps' are illustrated in Fig. 5 to 15, with their positions within the Meads of St. John hydrofracture system being shown on Fig. 2 and 16. Graphic logs of measured sections through parts of the hydrofracture system included within the thin sections (N12282; N12283; N12291; N12284; N12286; N12288) are shown in Fig. 17 (location of logged sections are shown on Fig. 6, 7, 9, $10,11)$. For ease of description the petrography of the sandstone bedrock and micromorphology of the sediment-fill associated with the bedding-parallel sills, steeply inclined dykes and late stage cross-cutting fissures which form the various components of the hydrofracture system will be described separately.

\section{Petrography of the sandstone bedrock}

In thin section (N12282; N12283; N12284; N12285; N12286; N12289) the bedrock is composed of a thinly-bedded (laminated to cross-laminated) to massive, moderate to well-sorted, matrix-poor, fine-grained, quartz-rich sandstone (quartz arenite). This clast-supported, moderately to open packed sandstone possesses a high intergranular porosity with the pore spaces being locally or partially filled by a highly birefringent clay cutan, especially near to the clay-rich margins of the hydrofractures. Angular to subangular, low sphericity detrital grains within the sandstone are mainly composed of monocrystalline quartz with minor to accessory feldspar, muscovite and biotite. Thin heavy mineral bands within the sandstone (N12286) are composed of granular opaque minerals, tourmaline, apatite, epidote and zircon. Cementation of the sandstone appears to have largely resulted from the variable pressure solution between quartzose grains during compaction and diagenesis. However, traces of hematite and/or cryptocrystalline quartzose rim cements are also present, either coating detrital grains and/or lining the intervening pore spaces.

Deformation structures developed within the bedrock associated with the Meads of St. John hydrofracture will be described in the following sections.

Micromorphology of the sediment-fill within the sill-like, bedding-parallel conduits Samples N12282, N12283 and N12291 were collected from the bedding-parallel sills which form the main feeders to the Meads of St. John hydrofracture system (see Fig. $2 \mathrm{D}, 16$ ). In thin section these sills are composed of finely laminated clay, silt and fine sand, with this stratification occurring parallel to the margins of the hydrofracture (Fig. 5, 6, 7). Both the lamination and margins of the hydrofracture are locally offset 
by a number of small-scale sub-vertical to steeply inclined normal faults (downthrow to the southeast). However, locally the sedimentary lamination appears to 'drape over' the small-scale ( 3 to $6 \mathrm{~mm}$ high) fault scarps formed as a result of the offset in bedrock at the margin of the hydrofracture (Fig. 6, 7); indicating that faulting probably occurred during sedimentation. Micromorphological analysis has revealed that the sills comprise three main phases of fill:

- Phase 1 (earliest) is composed of thinly laminated clay, silt and fine sand which forms a 5 to $25 \mathrm{~mm}$ thick layer immediately adjacent to the margin of the hydrofracture (Fig. 5); consistent with this clay-rich fill having been formed first. Similar clay-rich units also occur within the main body of the sediment-fill recording major changes in flow regime during the evolution of the hydrofracture;

- Phase 2 fills are composed of massive to laminated coarse silt and/or fine sand which locally preserved sedimentary structures (Fig. 5, 6, 7), providing a record of palaeoflow towards the northwest (parallel to the main ice movement direction) and fluctuating porewater pressure during deposition;

- and Phase 3 (latest) later stage liquefaction of earlier fills and injection of cross-cutting veinlets of homogenised sand and silt. These sandy fills are typically massive or possess a diffuse, cloud-like mottling consistent with their ?rapid deposition from dilated pulses of liquefied sediment.

The laminated clay, silt and sand which characterise the Phase 1 fill show varying degrees of deformation and disruption. These early fine-grained fills are locally connected to, or are fed by, clay- and silt-rich veins formed along the normal faults which deform the adjacent bedrock (Fig. 6, 7, 17A, B, C). The clay laminae possess a locally well-developed bedding-parallel plasmic fabric which also occurs parallel to the wall of the hydrofracture.

In sample N12282, a 15 to $20 \mathrm{~mm}$ thick clay-rich layer (Phase 1 fill) shows very little evidence of deformation, the latter being limited to a small number of moderate to steeply inclined, northerly dipping normal faults which downthrow towards the northwest (Fig. 5). The thin fine sand to coarse silt laminae within this clay-rich unit possess irregular erosive bases and preserve primary sedimentary structures including normal and reverse grading (Fig. 5, 17A). The graded laminae locally possess a distinct basal layer composed of highly dilated, open-packed, matrix-supported sand or silt (see Fig. 17A) in which the detrital grains occur within a matrix of highly birefringent clay cutan. On Fig. 17A, the grain size and thickness of the laminae within the Phase 1 fill increase upwards through the sequence preserving an apparent coarsening- and thickening upward cycle. Although highly deformed, possible thinning and fining upwards sequences maybe preserved within the Phase 1 fill in sample N12283 (Fig. 17B). The preservation of these systematic variations in sedimentation indicate that these sediments were, at least in part, deposited by water flowing through the hydrofracture system, rather than having formed in response to the injection of a liquefied (dilated) or highly plastic (deformable) sediment 'slurry' into the developing fracture.

In samples N12283 (Fig. 6) and N12291 (Fig. 7) the early clay-rich fill is highly deformed with the lamination being off-set by moderately to shallowly, northwesterly dipping normal faults and extensional shears, and/or distorted by complex disharmonic to convolute-style folds (Fig. 6, 7, 8). The fine-scale lamination and bedding-parallel plasmic fabric within the clay laminae locally possess an 
asymmetrical, S-C-like fabric geometry which records a sense of shear towards the northwest (Fig. 8B), parallel to the main ice movement direction. The shearing of the clays leading to the development of the S-C-like fabric may have occurred in response to displacement across the hydrofracture as it was reactivated during a later phase/stage of fluid flow. All of these structures are truncated by the base of the overlying, relatively later sand-rich fill (see Fig. 6, 7, 8), indicating that deformation occurred prior to the introduction of the Phase 2 fill. The silts within the Phase 1 fill also show evidence of having undergone varying degrees of liquefaction and remobilisation during deformation to form highly irregular, lenticular veinlets which are both off-set (predate) or crosscut (postdate) the faults and other small-scale deformation structures.

Sand-rich Phase 2 fills within the sill-like feeders to the hydrofracture system also show evidence of deformation (see Fig. 5, 6, 7). In sample N12282, the laminated Phase 2 sands and silts are deformed by a set of moderately to steeply, northwestdipping normal faults (Fig. 5). However, where deformation is less intense, primary sedimentary structures are preserved, these include graded bedding (normal and reverse; Fig. 5, 6), cross-lamination (Fig. 5) and convolute-bedding, with the latter being associated with soft-sediment deformation and liquefaction of the sands and silts (Fig. 6). Small-scale water-escape and injection features are also present. Thin, graded laminae within the individual sand layers are interpreted as having been deposited by repeated pulses of sand deposition, with the changes in grain size recording fluctuations in energy regime and sediment supply during a single flow event. The cross-lamination, where present, records an apparent north-westerly directed palaeoflow within the hydrofracture. Loading/compression required to induce syn-sedimentary soft-sediment deformation may have occurred in response to either: (i) the closing of the hydrofracture as the overpressures fell at the end of an individual flow event; or (ii) disturbance of an earlier, water-saturated sand layer due to the overflow of highly pressurised water during a later flow event.

The margins of the Phase 2 sand-rich fills are locally marked by thin clay partings (see Fig. 17B). The coarse, to pebbly bases to the sand layers locally possess an open-packed, matrix (clay cutan)-supported texture, consistent with these layers having being deposited from highly dilated, water-rich pulses of liquefied sediment. The clean (matrix-poor) sands are moderately to poorly sorted and mainly composed of angular to subangular grains of monocrystalline quartz with minor detrital feldspar, muscovite and biotite. Accessory heavy minerals include opaque minerals, epidote, zircon, apatite, amphibole, titanite, clinozoisite and garnet. The composition of the sands is comparable to the sandstone bedrock, suggesting that the sediments filling the hydrofracture were largely derived from these Devonian sedimentary rocks. In the finer grained sands and silt, the detrital micas and needle-like opaque oxides may exhibit a preferred shape alignment parallel to the lamination (primary sedimentary alignment of grains). Measured sections through the Phase 2 fills (Fig. 17A, B) record the presence of coarsening upward cycles of sedimentation within these sand-rich sequences. This coupled with the presence of normal and reverse graded sand laminae, as well as cross-lamination indicates that these sediments were deposited by water flowing through an open, but fluid-filled, cavity or void (or linked series of cavities) within the hydrofracture system. Coarsening and fining upwards cycles of sedimentation were also identified within samples N12288 (Fig. 17F) and N12284 (Fig. 17D), respectively, indicating pulses of water flow and sedimentation on either a rising or waning flow regime. 
Both the Phase 1 and 2 fills are locally cross-cut and, therefore, post-dated by irregular veinlets and patches of fine to coarse, massive sand (Phase 3 fill) which contain angular to irregular fragments of clay and laminated silt and clay detached from these earlier deposits (Fig. 5, 6). Veins of massive/homogenous sand were also noted cutting the adjacent sandstone wall-rock (Fig. 5).

Micromorphology of the steeply inclined, transgressive dyke-like sections of the hydrofracture system

The same three phases of sediment-fill have been recognised within the thin sections (N12284, N12285, N12286, N12288) taken from within the steeply inclined dyke-like sections of the hydrofracture system. However, the relationships between the Phase 1, 2 and 3 fills are far more complex (see Fig. 9 to 12). Graphic logs of measured sections through the sediments filling the dykes are shown in Fig. 17D, E, F. These reveal that there is a more rapid alternation between the three phases of fill within the dykes when compared to the sills, and that these individual packages of sediment are typically thinner.

Sample N12284 was collected from within the area where a sill-like feeder conduit joins a steeply inclined dyke section of the hydrofracture system (see Fig. 2D, 16). Both macro- (Fig. 2C) and microscopically (Fig. 9), the lamination within the Phase 1 and Phase 2 fills can be seen to steepen upwards from the sill into the dyke, indicating that fluid flow was diverted upwards at some point during the evolution of the Meads of St. John hydrofracture system. In thin section the earlier formed clay and silt-rich Phase 1 fill is highly disrupted and deformed by a number of low-angle to sub-horizontal shears which locally occur parallel to the margin of the vein. Bedding within the sandier Phase 2 fill is offset by a number of steeply inclined to sub-vertical normal faults which downthrow towards the southeast (Fig. 9). The laminated (structured) early fills are cross-cut and locally overprinted/replaced by irregular to patchy veinlets of massive Phase 3 sand and silt. Examples also occur where the Phase 2 sandy laminae grade laterally into the massive, structureless Phase 3 sand accompanied by a gradual loss of the earlier formed sedimentary structures. This relationship suggests that the Phase 3 fill, rather than being purely derived from sediment being introduced from outside the hydrofracture system, was partially derived from the liquefaction and remobilisation of the earlier formed fill. Small-scale syn-sedimentary normal faulting in sample N12284 (Fig. 9) may have occurred in response to extensional collapse of the preserved earlier fill as liquefaction and remobilisation led to the removal of the water saturated sand laminae during Phase 3. Evidence of erosion at the base of some of the Phase 2 sand laminae clearly indicates that earlier formed sediment-fill was periodically undergoing active erosion. The combination of active erosion, coupled with post-depositional liquefaction and remobilisation, would have potentially led to the localised 'flushing out' of an earlier sand and silt fills from one part of the hydrofracture, and its resedimentation elsewhere within the system during waning flow.

Samples N12286 (Fig. 10) and N12288 (Fig. 11) were both taken from the upper part of the dykes where they connect with the more gently inclined sills (see Fig. 16). In both samples, the three phases of fill define a well-developed stratification/layering parallel to the margins of the dyke. Veins and patches of massive Phase 3 sand occur both parallel, but also cross-cut this stratification. The preservation of possible coarsening and thickening 'upward' cycles within the Phase 2 fill in sample N12288 (Fig. 17F) indicates that sedimentation occurred in response to over-pressurised meltwater flowing along an open fluid filled fissure, rather than the 
simultaneous injection of liquefied sand into the dyke as it opened. The presence of variably rounded clay and silt 'intraclasts' within the Phase 2 fill (see Fig. 17D, F) indicate that the earlier formed fills were being eroded, possibly as a result of increasingly turbulent, over pressurised water being forced upwards into the opening dyke. However, elsewhere within the hydrofracture system, the strong electrostatic bonds formed between the clay plasma may have led to an increase in the shear strength and preservation potential of these earlier formed fine-grained fills. Phase 1 clay-rich fills preserved within the dykes are highly deformed and disrupted (Fig. 10, 11). The less deformed Phase 2 sandy fills are dissected by a number of south-easterly dipping normal faults which are coplanar with the margins of the dykes (Fig. 10). Faulting is thought to have occurred in response to the repeated reactivation of the dykes and partial collapse of the pre-existing sediment-fill into the hydrofracture as it opens during the earlier stages of a flow event. Minor normal faulting in the upper northwest corner of sample N12288, above a southeast dipping slab of massive sand, is associated with a wedge-shaped unit of laminated silt and sand (Fig. 11). Faulting is concentrated along the northern side of this unit with the sediment thickening towards this faulted margin, resulting in a microscale half-graben-like structure. The pronounced displacement gradients developed along the faults and draping of the laminae across these brittle structures are consistent with faulting having accompanied sedimentation. This synsedimentary faulting probably occurred during the progressive opening of the dyke resulting in the gradual collapse of the slab of massive sand, the opening of a small void above this down faulted block (downthrow towards the southeast). This void space was simultaneously filled by a coarsening upwards sequence of silt and sand, to form a wedge-shaped cap upon the massive sand.

The sedimentary lamination in the Phase 2 sand layers within the dykes is locally sub-horizontal occurring at a high-angle to the margins of the dyke, and the steeply inclined stratification within this part of the hydrofracture system (Fig. 10, 11). A similar relationship can be seen within a sub-vertical, small-scale sand and clay-filled vein located in the upper, southeast corner of sample N12284, where a meniscus-like lamination occurs at a high-angle to the vein margin (Fig. 9). The inclined stratification/layering within the dykes is likely to have formed in response to the repeated opening and fill (crack-seal) of dyke-parallel fissures. However, the subhorizontal lamination present within some Phase 2 fills clearly records deposition within an open, fluid-filled fissure. Once open the void is progressively filled (bottom to top) by the laminated sand and/or silt, either during a single or multiple flow events, leading to bedding at a high-angle to the dyke walls. This relationship also indicates that fluid flow periodically occurred parallel to the strike of the dyke, rather axially along the hydrofracture (towards the northwest) as recorded by the crosslaminated sands within the sills.

Sample N12285 was taken from close to the southern margin of a steeply inclined dyke-like section of the Meads of St. John hydrofracture system (Fig. 16). The thin section is dominated by the sandstone wall-rock which is cut by a zone of closely spaced, steeply inclined, southeast-dipping normal faults which are lined by thin veinlets of Phase 1 clay and silt (Fig. 12). These faults form part of a 10 to 15 $\mathrm{mm}$ wide fault zone which controlled/denotes the margin of the dyke. The sandstone wall-rock adjacent to this dyke is permeated by an irregular, patchy network of massive sand (Phase 3) which possesses a clay cutan cement or matrix (Fig. 12). The margins of this network are highly irregular with the sand containing rounded to irregular fragments of sandstone. Importantly the lamination within the sandstone 
fragments can be traced laterally into the adjacent wall-rock (see Fig. 12) indicating that these blocks have not been rotated/displaced during the introduction of the sand.

The stratified sediment-fills within the dykes also contain angular to rounded fragments of sandstone detached from the adjacent bedrock during hydrofracturing (Fig. 10,11). Rounding of these bedrock clasts probably occurred as a result of the erosive action (abrasion) of the overpressured, sediment ladened water flowing through the dyke.

\section{Micromorphology of the late stage, cross-cutting fissures}

Three samples (N12287, N12289, N12290) were collected from the irregular fissures (Fig. 16) which cut across the earlier formed sills and dykes, clearly truncating the layering within these parts of the hydrofracture system (see Fig. 2D, C). In thin section these fissure-fills are dominated by a complex patchwork of massive to mottled sand and silty sand (Phase 3) (Fig. 13, 14, 15). Blocky to irregular fragments and veinlets of Phase 2 sand and Phase 1 clay-rich fills are preserved as relicts within these sand dominated fissures. In sample N12289, laminated Phase 2 sands are preserved as a thin, normally faulted unit along the steeply dipping, northern margin of the fissure (Fig. 14). The bedrock immediately adjacent to the fissure in sample N12290 is brecciated (Fig. 15), with the sandstone locally being permeated by an intergranular pore lining or filling clay cutan. The highly complex, irregular, mottled to 'cloud-like' pattern of clean, matrix-poor sand and silty sand (see Fig. 13, 14) which characterises the Phase 3 within samples N12287, N12289 and N12290 is consistent with their formation in response to the repeated injection and partial mixing of highly dilated, liquefied sand. The lack of any significant organisation (stratification) within these Phase 3 sediments clearly reflects a major change between the system controlling the progressive development of the earlier formed dykes and sills, and that active during the formation of the later fissures (see below).

\section{A comparison of the results of Meads of St. John micromorphology study with published engineering hydraulic fracturing data and the implications for the development of subglacial hydrofractures}

\section{Fracture propagation and sedimentation within subglacial hydrofractures}

A comparison of published hydraulic fracturing test data with the macro- and microstructures developed within the Meads of St. John hydrofracture system has revealed that the timing and style of sedimentation and deformation associated with the development of this system can be directly related to the changes in fluid overpressure during hydraulic fracturing (Fig. 18). Hydraulic fracturing, also referred to as 'fracking' or 'hydrofracking', is a process used in industry to increase the permeability of a reservoir in order to release petroleum, natural gas, coal seam gas, or other substances for extraction. Fractures are initiated and subsequently propagated within a rock layer by means of injecting a pressurized fluid into the rock via a borehole.

Figure 18A shows the changes in fluid (water or water + sediment) pressure over time during a single idealised hydraulic fracturing event or 'flow event'. Prior to hydrofracturing the fluid overpressure increases to a maximum (P max on Fig. 18A) which exceeds the Youngs modulus (E) or stiffness of the bedrock (for sandstone $\mathrm{E}$ is approximately $40 \mathrm{GPa}$ ) leading to failure and hydrofracture propagation. Fracture growth occurs in the direction of decreasing load or vertical stress (Murdock 1995); in a subglacial or submarginal setting the propagation direction would be down-ice, 
towards the ice margin (van der Meer et al. 1999, 2008). Pollard \& Holzhausen (1979), Abou-Sayed et al. (1984) and Murdock (1995) demonstrated that hydraulic fractures typically turn upwards, propagating towards the ground surface as the load decreases, with the fracture dipping towards its point of inception. The geometry of the feeder sills and interconnecting dykes which form the Meads of St. John hydrofracture system show that it 'climbs' towards the north. This, coupled with a northerly palaeoflow direction recorded by sedimentary structures within the system, are consistent with the Meads of St. John hydrofracture system having propagated towards the north (down-ice) with its inception occurring beneath the margin of the Findhorn glacier probably after it had decoupled from the main MFIS.

Modelling carried out by Brenner \& Gudmundsson (2004) has shown that within an active hydrofracture the overpressure varies linearly from a maximum at its centre to zero at the propagating tip. The fluid front, marking the leading edge of water penetration into the hydrofracture, may coincide with the fracture tip, or alternatively, where fracture propagation is facilitated by the presence of a preexisting plane of weakness, the hydrofracture may propagate ahead of this front. Where the fracture propagates in advance of the fluid front, Brenner \& Gudmundsson (2004) recorded the presence of an 'unwetted' or 'dry zone' between the fluid front and fracture tip. In the case of the Meads of St. John hydrofracture system, the sills which form the main feeder conduits to the system, propagated along bedding. Consequently, a 'dry zone' is likely to have temporarily existed between the propagating tip and advancing fluid front (Fig. 19A). As fluid penetrated the rapidly developing fracture the overpressures rapidly increased leading to a widening of the aperture, allowing increased flow of water and sediment into the system (Fig. 19A).

The earliest phase of sedimentation within the Meads of St. John hydrofracture is the clay-rich Phase 1 fill. In lacustrine and/or fluviatile environments, for example the deposition of clay is typically equated with low-energy conditions. In hydrofractures, however, such conditions are very short lived. At the end of a flow event the rapid decrease in overpressure leads to the closure of the system and termination of sedimentation (Fig. 18A), hence there is very little or no time for the clays to have been deposited by settling out of suspension. High fluid overpressures are required to break the electrostatic bonds between the clay plasma allowing these very fine-grained sediments to be liquefied and transported along the hydrofracture system. Microtextural evidence clearly demonstrates that Phase 1 clay-fills formed during the earliest stages of the opening of the Meads of St. John hydrofracture system when fluid overpressures were at their highest (see Fig. 18). Consequently, the Phase 1 clays are most likely to have deposited within the zone of relatively lower overpressure formed at the leading edge of the fluid front as it penetrated along the propagating hydrofracture (Fig. 19A). The well-developed plasmic fabric within the Phase 1 clays, parallel to the hydrofracture margins may have formed in response to these fine-grained sediments being 'plastered' to the fracture walls as the watersediment mix was introduced into the widening fracture. Deformation of the clay-rich Phase 1 fills (see Fig. 5, 6, 7, 8) may have occurred in response to the reopening of the hydrofracture during subsequent flow events, or alternatively shearing induced by the continued movement of overpressurised fluid to into the expanding hydrofracture during a single flow event.

The permeability and porosity of sandstone wall-rock can be seen to vary on a small-scale (see above), reflecting subtle changes in sediment packing, cementation and matrix component. In thin section, pore spaces within this matrix-poor sandstone, immediately adjacent to the hydrofracture, are locally lined or filled by clay cutan. 
This cutan is absent elsewhere within the bedrock and is therefore interpreted as having been introduced by pressurised water 'bleeding out' from the hydrofracture and into the wall-rock. Penetration of over-pressurised fluid into the more permeable areas within the sandstone probably coincided with the advance of the fluid front towards the propagating tip (see Fig. 19A). The combined effect of blocking open pore spaces within the sandstone and 'plastering' of Phase 1 clay to the walls of the hydrofracture would have effectively sealed the adjacent permeable bedrock concentrating subsequent 'peak' fluid flow within this fracture.

After the initial high (P max) values, fluid pressure initially falls rapidly as the fracture propagates through the bedrock and is followed by a more 'stable period' of elevated water overpressure when $\mathrm{P}$ decreases more gradually (Fig. 18A). Sedimentary structures preserved within the sand-rich Phase 2 fill (Fig. 19B), in particular ripple drift lamination, are consistent with these sediments having been deposited by water flowing within an open, fluid-filled void or cavity. This provides unequivocal evidence that fluid overpressures were high enough to maintain an open aperture (or series of linked apertures/cavities) with the pressurised water acting as a 'hydrogeological jack'. Normal and reverse grading of the sand laminae, however, demonstrates that small-scale variations in fluid flow/pressure occurred during deposition (Fig. 18A). The repetition of thin, graded sand laminae within a single layer of Phase 2 sands suggests that fluid flow did not take the form of a continuous 'stream', but was 'pulsed'. This pulsing of sediment fill may record a 'crack-and-fill' style of deposition during Phase 2, were individual sand laminae record the incremental opening and filling of the hydrofracture. Alternatively, the hydrofracture may have remained open throughout the flow event with constrictions at narrow points within the system influencing fluid flow, leading to small-scale fluctuations in overpressure.

At the end of the flow event the fluid overpressure fell rapidly (Fig. 18A) leading to the shutting down the hydrofracture system. This may have occurred as the source of overpressurised fluid become exhausted, or the hydrofracture became choked/sealed with sediment. The fall in overpressure would have removed the force maintaining the void spaces within the system, leading to closure of the walls of the hydrofracture and the loading (compression) of the sedimentary fill; potentially resulting in the locally observed soft-sediment deformation (see Fig. 6, 19B).

Hydraulic fracturing within wells and boreholes typically only requires a small number of overpressure events to achieve the required increase in flow from the reservoir. However, available test data indicate that the magnitude of the overpressures ( $\mathrm{P} \max$ ) needed to achieve this effect decreases with each successive phase of hydraulic fracturing (P1 to PN on Fig. 18B), with the duration of the overpressure events also decreasing with time (Flow Events 1 to $\mathrm{N}$ on Fig. 18B). If applicable to natural hydrofracture systems, this would have important implications for the development and longevity of subglacial hydrofracture systems, effectively placing a time limit on their period of activity. Essentially, the hydrofracture would be progressively abandoned as the scale of the flow events eventually became too small to reactivate the system. Repeated phases of hydraulic fracturing will also lead to an increase in the permeability of the glacier bed, facilitating the movement of water through this environment. This repeated reactivation and/or development of new hydrofractures systems also has the potential to lead to the weakening of the bed, increasing bedrock erosion, promoting the detachment of bedrock blocks and rafts. An increase in bed permeability will modify the subglacial hydrogeology, potentially decreasing its ability to generate the overpressures required to promote further 
hydrofracture development. Consequently, intense hydrofracturing of the bed of a glacier or ice sheet may be a self-limiting process, the 'safety valve' of van der Meer et al. (2008), once the pressure has been released the 'safety valve' is closed/abandoned.

The complexity of the hydrofracture system exposed at the Meads of St. John indicates that it was active over a prolonged period of time. Studies of the hydrogeology of modern glaciers and ice sheets have shown that meltwater discharge varies on a range of scales from daily, to yearly, to longer decadal cycles (see Benn \& Evans 1998; Boulton 2006 and references therein). Such variations lead to the repeated build up of meltwater content and pressures in the subglacial environment. As a result, rather than being a relatively simple progression recording decreasing overpressure leading to hydrofracture abandonment as shown in Fig. 18B, in reality the evolution of more complex hydrofracture systems is likely have been punctuated by several periods of elevated fluid overpressure (Fig. 18C), perhaps separated by periods of quiescence when the hydrofracture system was inactive. Such repeated increases in $\mathrm{P}$ max could lead to either: (i) the reactivation of the existing hydrofracture system resulting in renewed sedimentation and/or the erosion/'flushing' of earlier formed fills (in particular less cohesive matrix-poor sands and silts); or (ii) fracturing of the adjacent wall-rock and 'break out' of the fluid to form the new sections to the system, such as the cross-cutting dykes, where the existing hydrofracture is completely choked/sealed with sediment; or (iii) a combination of these, where the two processes occur simultaneously in different parts of more extensive hydrofracture systems. The complex interplay between the 'flushing out' of sediment within one part of the system coupled with renewed hydrofracturing elsewhere in the same system could lead to the development of the complex crosscutting fissures filled by the structureless Phase 3 fill observed within the Meads of St. John hydrofracture system.

\section{Mode of sediment deposition and/or emplacement}

Larsen \& Mangerud (1992) recognised three potential modes of formation of subglacial dyke-like hydrofractures (also see van der Meer et al., 2008): (i) instantaneous cut and fill; (ii) squeeze-in of till or other plastic material driven by the movement and load provided by the overriding glacier; and (iii) the injection of a water-sediment mixture into the hydrofracture in a series of several successive pulses, with the widening of the fissure and simultaneous deposition of each laminae.

Detailed micromorphological analysis of the sediments filling the Meads of St. John hydrofracture system has revealed that subglacial hydrofractures can also be filled by more "fluviatile-like" depositional processes with style of sedimentation varying in different parts of the system. As noted above, the preservation of primary sedimentary structures (in particular cross-lamination) in the sand-rich Phase 2 fills within the sills (Fig. 19) is consistent with these sediments having deposited by water flowing through interconnected voids or cavities within the hydrofracture. This linked system must have acted like temporary, small-scale drainage channels, focusing fluid flow and allowing the formation and migration of ripples, and similar sedimentary structures typically equated with deposition in a fluviatile system.

In the steeply inclined dyke-like sections, the thin, slab-like layers of Phase 2 sand form a marked banding/stratification parallel to the dyke margins. The internally structureless nature of these layers is consistent with the simultaneous injection of a layer of water saturated sediment into a dyke-parallel fissure(s) (c.f. type 3 fill of Larsen \& Mangerud 1992), rather than deposition from flowing water. However, the 
presence of a horizontal sedimentary lamination in some Phase 2 sand layers (Fig. 10, $11,17 \mathrm{~F}$ ) is thought to record the progressive build-up of sediment in an open, fluidfilled, steeply inclined fissure/void formed within the dyke. This requires a marked change in the mode of formation of the dykes from an incremental opening and simultaneous fill of dyke-parallel fissures, to a single phase of deformation leading to the formation of an open fracture which is 'passively' filled by sediment laid down by water flowing though this void.

Phase 3 fills typically occur within irregular veins and/or patches within both the sills and dykes, or filling larger late-stage fissures which cross-cut the earlier parts of the hydrofracture system (see Fig. 2, 13, 14, 15, 19, 20). The micromorphological characteristics of these late fills clearly indicates that their mode of deposition is very different to the more structured Phase 1 and Phase 2 deposits. The typically massive, structureless to mottled (cloud-like) character of the Phase 3 fill is consistent with the rapid injection of highly dilated, liquefied sand into both the hydrofracture and adjacent wall-rock. Veinlets of Phase 3 sand can be traced laterally into the laminated Phase 2 sediments, indicating that the later phase of fill was partially derived from the liquefaction and remobilisation of these earlier formed sandy deposits, rather than being solely introduced from outside the system. The presence of angular to rounded fragments of the earlier formed fills and localised brecciation of Phase 1 and 2 sediments, are consistent with disruption caused by the forceful emplacement of the liquefied sand during Phase 3.

The essentially structureless nature of Phase 3 fills, when compared to the earlier formed fills, points to a distinct change in the nature of the hydraulic fracturing during the later stages of the evolution of the Meads of St. John hydrofracture system. One possible interpretation is that Phase 3 development occurred in response to a sudden failure within the hydrofracture and/or adjacent bedrock, leading to marked and/or rapid fluctuations in fluid overpressure, promoting either the brecciation or localised liquefaction, remobilisation and 'flushing' of the earlier fills, followed by injection. The response of the pre-existing sediment will be dependent upon its water content, with brecciation occurring where the earlier fill has dewatered, and liquefaction where the typically sandy sediments still possess a relatively high porewater content. This variation in response also indicates that there was sufficient time between flow events for earlier deposits to dewater, pointing to a relatively prolonged history of fluid flow within the Meads of St. John hydrofracture system (see below).

The above relationships clearly indicate that sedimentation within subglacial hydrofracture systems can be far more complex than previously thought. In particular, the style of sedimentation can change over time, with the morphology, orientation and processes responsible for hydrofracture propagation also influencing fracture-fill.

\section{Evolution of the Meads of St. John hydrofracture system}

The macro- and microscopic complexity of the Meads of St. John hydrofracture system clearly indicates that subglacial hydrofractures can be active over a prolonged period and can accommodate several phases of propagation, fluid flow and sedimentation. The simplified morphology of the hydrofracture system is shown in Fig. 20, with the cross-cutting relationships between its various components enabling a relative chronology between the sills and dykes to be established. Macroscopically (field observations), this step-like hydrofracture system 'climbs' towards the north with in theory only one part of the system being active at any one time (c.f. Kumpulainen 1994). The progressive evolution of the Meads of St. John 
hydrofracture system is illustrated in Fig. 21. The potential relationship of this evolving system to the margin of the Findhorn glacier is shown in Fig. 22.

The earliest formed part of the system are the gently northerly (down-ice) dipping, bedding-parallel feeder sills (labelled 1 and 2 on Fig. 20A; Event 1 and 2, Fig. 21). Published engineering hydraulic fracturing studies rely upon fluid overpressure being the sole driver for hydrofracture development (e.g. Pollard \& Holzhausen 1979; Abou-Sayed et al. 1984; Murdock 1995; Flekkøy et al. 2002; Brenner \& Gudmundsson 2009) with the angle of dip and the length of sub-horizontal sections (sills) of the fractures being related to the depth of the inception point down a borehole with these artificially generated hydrofractures being inclined towards this inception point (Murdock 1995). In contrast, the sills within the Meads of St. John (this study), and similar hydrofractures described from the forefield of Slettjökull, Iceland (van der Meer et al. 1999, 2008), dip in a down-ice direction, i.e. away from their source. The differential load provided by the thinning of the glacier or ice sheet towards its margin (see Fig. 22) is thought to be the primary control on the direction of hydrofracture propagation and fluid flow (cf. Piotrowski 2006; van der Meer et al. 2008). During the early stages of its evolution, the orientation and lateral extent (up to several tens of metres) of the feeder sills to the Meads of St. John hydrofracture system were also controlled by the dip and strike of bedding within the host bedrock (Fig. 21A, B). In the case of natural hydrofracture systems, the overall simple shear style of subglacial deformation imposed on the bed by the overriding ice would have also facilitated their development (Fig. 22A). For example, the down-ice orientation of the sills within the Meads of St John hydrofracture system means that they would have been developing parallel/sub-parallel to either $C^{\prime}$-type shear bands (ductile) or R-type Riedel shears (brittle) (see Passchier \& Trouw 1996; figs 5.17, 5.34,) forming in response to subglacial simple shear. The resultant extension occurring across the developing sills, indicated by the syn-sedimentary NW-directed normal faults and thrusts deforming both Phase 1 and 2 fills (Fig. 5, 6, 7, 8), coupled with the elevated fluid overpressures, would have not only aided hydrofracture propagation along bedding, but also facilitated the widening of these features so that they could accommodate fluid flow and sediment deposition.

At some point during its evolution, the northerly (down-ice) propagation of the main feeder sills appears to have been arrested and the overpressurised water began to break through the bedrock within the hanging-wall of these features, forming a series of steeply inclined dykes (Events 3 to 6; Fig. 21). This may have occurred due to the hydrofracture system becoming choked/sealed with sediment and/or a marked increase in fluid overpressure (Fig. 18C) due to a rise in the volume of meltwater being fed into the subglacial hydrogeological system. Deformation within the hanging-walls of the main feeder sills resulted in localised normal (extensional) faulting (Fig. 21C-F), facilitating the upward escape of the overpressurised water and sediment. The relative age of the dykes changes systematically from northwest to southeast (labelled 3, 4, 5, 6 on Fig. 20), with the cross-cutting relationships indicating that, in general, they become progressively younger in an up-ice direction (Fig. 21C-F). The dykes connect a series of gently inclined to bedding-parallel sills resulting in the 'climbing' of hydrofracture system towards the NW, i.e. down-ice (Fig. 20, 21).

Engineering studies have shown that hydraulic fractures 'climb' upwards towards the ground surface as a result of the inherent density contrast between the injected fluid and the host material, driving the escaping water-sediment mix towards the surface (Abou-Sayed et al. 1984), as well as the interaction of the developing 
fracture with the overlying sloping ground surface (Pollard \& Holzhausen 1979; Murdock 1995). In the case of the Meads of St. John hydrofracture system there appears to have been a change in the stress regime beneath the Findhorn glacier between the formation of the main feeder sills (Events 1 and 2; Fig. 21) and the later dykes (Events 3 to 6; Fig. 21). The upward migration of this, and similar ice-marginal to subglacial hydrofracture systems, probably occurs in response to a combination of ground surface effects, decreasing vertical load (pure shear) as the ice thins towards its margin, and the buoyant force provided by the escaping overpressurised watersediment. The earlier stages of the evolution the Meads of St. John hydrofracture system may have been entirely subglacial with the overriding Findhorn glacier exerting a vertical (overburden) stress confining fracture propagation to within the bedrock (Fig. 22A). However, as the glacier retreated southwards and the thinner ice at its margin migrated towards the Meads of St. John, the resultant decrease in the thickness of the Findhorn glacier in this submarginal setting would have resulted in a decrease in the vertical overburden stress imposed on the underlying bed. This would have allowed the developing hydrofracture system to start to climb, propagating upwards towards the surface in a series of connected dykes and sills (Fig. 22B). The progressive southward retreat of the ice and the associated changes to the vertical overburden stress regime would have also resulted in the dyke-like sections becoming progressively younger in an up-ice direction. It is possible that the rate of climb or steepness of submarginal hydrofractures may be partially controlled by the surface gradient of the ice front. For example, steep ice margins may promote a relatively steep angle/rate of climb as the vertical overburden stress exerted by the ice and its surface elevation decrease over a much shorter distance (Fig. 22). This would also lead to an increase in the gradient of the glacial hydrogeological system within submarginal environments, facilitating the upward migration of the overpressurised fluid. In contrast, the gradual decrease in the vertical overburden stress and the accompanying effect to the in situ stress regime associated with the more gently inclined ice margins may result in a much lower rate of climb and, therefore, more gently inclined submarginal hydrofracture systems (Fig. 22).

The later stages of the evolution of the Meads of St. John hydrofracture system (Event 8; Fig. 21) were dominated by the intrusion of the cross-cutting, irregular fissures filled by structureless Phase 3 sands (labelled 8 on Fig. 20). At this stage bedding within the sandstone no longer appeared to be influencing hydrofracture propagation. This may indicate that the repeated fracturing of the sandstone had sufficiently weakened the bedrock that fracture propagation was no longer constrained to pre-existing planes of weakness. Alternatively, these late stage fissures may record the further retreat of the Findhorn glacier margin (Fig. 22C). The in situ stress regime encountered in an ice marginal to proglacial setting would be significantly different than those encountered beneath the ice allowing the overpressurised fluid to overcome the strength of the overlying bedrock. Although there is no evidence for the Mead of St. John hydrofracture system having 'breached' the surface, it is possible that ice marginal hydrofracture systems form the plumbing systems to 'blow out' structures.

If the proposed relationship between the various stages of the evolution of the Meads of St. John hydrofracture system and the retreat of the Findhorn glacier is correct, then it would suggest that more complex hydrofracture systems can be reactivated several times over a period of decades.

\section{Conclusions}


A number of conclusions can be made regarding the propagation and sedimentation within hydrofractures based upon the detailed micromorphological study of a complex system cutting Middle to Upper Devonian sandstone bedrock exposed at the Meads of St. John, near Inverness (NE Scotland):

- Hydrofracture systems can be complex multiphase systems which may be active over a prolonged period and accommodate several phases of fluid flow and sedimentation. Three main phases of fill have been recognised within the Meads of St. John Hydrofracture system: Phase 1 - clay-rich fills lining the hydrofracture and effectively sealing the adjacent wall-rock reducing its permeability; Phase 2 - laminated sand-rich fills deposited as a result of the repeated reactivation of the hydrofracture system; and Phase 3 - late-stage, structureless sandy fills infilling irregular, cross-cutting veins.

- Subglacial to ice marginal hydrofracture systems may propagate along preexisting structures (e.g. bedding) present within the host sediment/bedrock and/or form crosscutting features resulting from contemporaneous deformation (faulting, fracturing).

- The differential load provided by the thinning of the glacier towards its margin is thought to exert the primary control on the direction of hydrofracture propagation and fluid flow through subglacial to ice-marginal hydrofracture systems (cf. Piotrowski 2006; van der Meer et al. 2008).

- A comparison of the results obtained during this micromorphological study with published engineering hydraulic fracturing test data indicates that deformation and sedimentation associated with natural hydrofracture systems can be directly related to the systematic variation in overpressure encountered during 'hydrofracking'.

- Repeated phases of hydrofracturing will lead to an increase in the permeability of the glacier bed, facilitating the movement of water through this environment. The resultant change in subglacial hydrogeology may limit the potential for generating the overpressures required to promote further hydrofracturing. Consequently, intense hydrofracturing of the bed of a glacier or ice sheet may potentially be a self-limiting process, the 'safety valve' of van der Meer et al. (2008).

- The evolution of the Meads of St. John hydrofracture system may be linked to the retreat of the Findhorn glacier after it has decoupled from the Moray Firth Ice Stream. The early stages of its evolution are thought to have been entirely subglacial with the vertical (overburden) stress exerted by the overriding ice confining hydrofracture propagation to within the bedrock. However, as the glacier retreated the marked decrease in vertical overburden stress beneath the ice margin, combined with the buoyant force provided by the less dense, overpressurised fluid, allowed the hydrofracture system to propagate upwards through the bedrock as a series of interconnected dykes and sills, with the rate of 'climb' possibly reflecting the surface gradient of the ice front. The development of the late stage, cross-cutting veins and fissures within the Meads of St. John hydrofracture system may have accompanied further retreat 
of the Findhorn glacier, with the overpressurised fluid breaking through the bedrock in an ice-marginal to possibly proglacial setting.

- The proposed relationship between the evolution of the Meads of St. John hydrofracture system and the retreat of the Findhorn glacier, if correct, may indicate that complex, subglacial to ice marginal hydrofracture systems can, in some instances, be repeatedly reactivated over a period of decades.

Acknowledgements. This work forms part of the Physical Properties of UK rocks and tills and Moray-Ness projects of the British Geological Survey. Clive Auton, David Entwisle, Jonathan Lee and David Boon are thanked for discussions in the field and comments on an earlier version of this manuscript. John Menzies and John Hiemstra are thanked for their constructive reviews of this paper. John Fletcher (BGS thin sectioning laboratory, Keyworth) is acknowledged for his expertise in making the thin sections. ERP is an associate member of the Centre for Micromorphology, Queen Mary, University London. This paper is published with the permission of the Executive Director of the British Geological Survey (NERC).

\section{References}

Abou-Sayed, A.S., Sinha, K.P. \& Clifton, R.J. 1984: Evaluation of the influence of insitu reservoir conditions in the geometry of hydraulic fractures using a 3-D simulator: Part 1 - Technical approach. SPE paper 12877. Proceedings Unconventional Gas recovery Symposium, Pittsburgh, PA, 433-438.

Benediktsson, I.O., Möller, P., Ingólfsson, O., van der Meer, J.J.M., Kjær, K.H. \& Krüger, J. 2008: Instantaneous end moraine and sediment wedge formation during the 1890 glacier surge of Brúarjökull, Iceland. Quaternary Science Reviews 27, 209-234.

Benn, D.I. \& Evans, D.J.A. 1998: Glaciers and Glaciation. 734 pp. Arnold, London.

Boulton, G.S. 2006: Glaciers and their coupling with hydraulic and sedimentary processes. In Knight, P.G. (ed.): Glacier Science and Environmental Change, 3-22. Blackwell, Oxford.

Bradwell, T., Stoker, M., Golledge, N., Wilson, C., Merritt, J., Long, D., Everest, J., Hestvik, O., Stevenson, A., Hubbard, A., Finlayson, A. \& Mathers, H. 2007: The northern sector of the last British Ice Sheet: maximum extent and demise. Earth Science Reviews 88, 207-226.

Brenner, S.L. \& Gudmundsson A. 2004: Arrest and aperture variation of hydrofractures in layered reservoirs. In Cosgrove J.W. \& Engelder, T. (eds): The Initiation, Propagation and Arrest of Joints and Other Fractures, 117-128. Geological Society of London Special Publication 231.

Broster, B.E. 1991: Glacitectonic deformation in sediment and bedrock, Hat Creek, British Columbia. Geographie physique et Quaternaire 45, 5-20.

Broster, B.E. \& Seaman, A.A. 1991: Glacigenic rafting of weathered granite: Charlie Lake, New Brunswick. Canadian Journal of Earth Sciences 28, 649-654. 
von Brunn, V. \& Talbot, C.J. 1986: Formation and deformation of subglacial intrusive clastic sheets in the Dwyka formation of northern Natal, South Africa. Journal of Sedimentary Petrology 56, 35-44.

Burbridge, G.H., French, H.M. \& Rust, B.R. 1988: Water escape fissures resembling ice wedge casts in late Quaternary subaqueous outwash near St. Lazare, Quebec, Canada. Boreas 17, 33-40.

Burke. E.R., Phillips, E.R., Lee, J.R. \& Wilkinson, I.P. 2009: Imbricate thrust stack model for the formation of glaciotectonic rafts: an example from the Middle Pleistocene of north Norfolk, UK. Boreas 38, 620-637.

Christiansen, E.A., Gendzwill, D.J. \& Meenely, W.A. 1982: Howe Lake: a hydrodynamic blowout structure. Canadian Journal of Earth Sciences 19, 1122-1139.

Davidson, S. \& Stoker, M.S. 2007: Ice streams and Ice Sheets Limits from the West Shetland Margin: The offshore view of the last British Ice Sheet in North-West Britain. Abstracts of Papers, Quaternary Research Association, Annual Discussion Meeting, St. Andrews.

Dionne, J.-C. \& Shilts, W.W. 1974: A Pleistocene clastic dike, Upper Chaudie re Valley, Quebec. Canadian Journal of Earth Sciences 11, 1594-1605.

Dreimanis, A. 1992: Downward injected till wedges and upward injected till dykes. Sveriges Geologiska Undersøgelse, Serie Ca 81, 91-96.

Dreimanis, A. \& Rappol, M. 1997. Late Wisconsinan sub-glacial clastic intrusive sheets along Lake Erie bluffs, at Bradtville, Ontario, Canada. Sedimentary Geology $111,225-248$.

Evans, D.J.A. \& Ó Cofaigh, C. 2003: Depositional evidence for marginal oscillations of the Irish Sea ice stream in southeast Ireland during the last glaciation. Boreas 32, 76-101.

Evans, D.J., Livingstone, S.J., Vieli, A., Ó Cofaigh, C. 2009: The palaeogeography of the central sector of the British and Irish Ice Sheet: reconciling glacial geomorphology and preliminary ice sheet modelling. Quaternary Science Reviews 28, 740-758.

Everest, J.D., Bradwell, T. \& Golledge, N.R. 2005: Subglacial landforms of the Tweed Palaeo-Ice stream. Scottish Geographical Journal 12, 163-173.

Firth, C.R. 1990: An excursion to view the evidence of changes in relative sea level during, and following the deglaciation of the coastal lowlands bordering the northern shore of the Beauly Firth and the southern shore of the Inverness Firth. In Auton, Firth, C.R. \& Merritt, J.W. (eds): Beauly to Nairn: Field Guide, 96-116. Quaternary Research Association, Coventry, England.

Flekkøy, E.G., Malthe-Sørenssen, A. \& Jamtveit, B. 2002: Modelling hydrofracture. Journal of Geophysical Research 107 B82151, 1-11. 
Frey, S.E., Gingras, M.K. \& Dashtgard, S.E. 2009: Experimental studies of gasescape and water-escape structures: mechanisms and morphologies. Journal of Sedimentary Research 79, 808-816.

Golledge, N.R. \& Stoker, M. 2006: A palaeo-ice stream of the British Ice Sheet in eastern Scotland. Boreas 35, 231-243.

Goździk, J. \& van Loon, A.J. 2007: The origin of a giant downward directed clastic dyke in a kame (Be1chatow mine, central Poland). Sedimentary Geology 193, 71-79.

Gudmundsson, A., Gjesdal, O., Brenner, S.L. \& Fjeldskaar, I. 2003. Effects of linking up of discontinuities on fracture growth and groundwater transport. Hydrogeology Journal 11, 84-99.

Kjær, K.H., Larsen, E., van der Meer, J.J.M., Ingólfsson, O., Krüger, J. Benediktsson, I.O., Knudsen, C.G. \& Schomacker, A. 2006: Subglacial decoupling at the sediment/bedrock interface: a new mechanism for rapid flowing ice. Quaternary Science Reviews 25, 2704-2712.

Knight, J., McCarron, S.G. \& McCabe, A.M., 1999: Landform modification by palaeo-ice streams in east-central Ireland. Annals of Glaciology 28, 161-167.

Kumpulainen, R.A. 1994: Fissure-fill and tunnel-fill sediments: expressions of permafrost and increased hydrostatic pressure. Journal of Quaternary Science 9, 5972.

Larsen, E. \& Mangerud, J. 1992: Subglacially formed clastic dykes. Sveriges Geologiska Undersokning Series Ca 81, 163-170.

Le Heron, D.P. \& Etienne, J.L. 2005: A complex subglacial clastic dyke swarm, Sólheimajökull, southern Iceland. Sedimentary Geology 181, 25-37.

McCabe, A.M. \& Dardis, G.F. 1994: Glaciotectonically induced water-through flow structures in a Late Pleistocene drumlin, Kanrawer, County Galway, western Ireland. Sedimentary Geology 91, 173-190.

van der Meer, J.J.M. 1987: Micromorphology of glacial sediments as a tool in distinguishing genetic varieties of till. In Kujansuu, R. \& Saarnisto, M. (eds): INQUA Till Symposium, Finland 1985, 77-89. Geological Survey of Finland, Special Paper 3.

van der Meer, J.J.M. 1993: Microscopic evidence of subglacial deformation. Quaternary Science Reviews 12, 553-587.

van der Meer, J.J.M. 1996: Micromorphology. In Menzies, J. (ed.): Glacial Environments: Volume 2; Past Glacial Environments - Processes, Sediments and Landforms, 335-355. Butterworth \& Heinemann, Oxford.

van der Meer, J.J.M., Kjær, K. \& Krüger, J. 1999: Subglacial water-escape structures, Slettjökull, Iceland. Journal of Quaternary Science 14, 191-205. 
van der Meer, J.J.M., Kjær, K.H., Krüger, J., Rabassa, J. \& Kilfeather, A.A. 2008: Under pressure: clastic dykes in glacial settings. Quaternary Science Reviews 28, 708720 .

Menzies, J. 2000: Micromorphological analyses of microfabrics and microstructures indicative of deformation processes in glacial sediments. In Maltman, A.J., Hubbard, B. \& Hambrey, M.J. (eds.): Deformation of Glacial Materials, 245-257. Geological Society of London Special Publication 176.

Merritt, J.W., Auton, C.A. \& Firth, C.R. 1995: Ice-proximal glaciomarine sedimentation and sea-level change in the Inverness area, Scotland: A review of the deglaciation of a major ice stream of the British Late Devensian ice sheet. Quaternary Science Reviews 14, 289-329.

Merritt, J.W., Auton, C.A., Connell, E.R., Hall, A.M. \& Peacock, J.D. 2003: The Cainozoic geology and landscape evolution of north-east Scotland. Memoir of the British Geological Survey, Sheets 66E, 67, 76E, 77, 86E, 87W, 87E, 95, 96W, 96E and 97 (Scotland).

Moran, S.R., Clayton, L., Hooke, R.L., Fenton, M.M. \& Andriashek, L.D. 1980: Glacier-bed landforms of the prairie region of North America. Journal of Glaciology $25,457-476$.

Murdoch, L.C. 1995: Forms of hydraulic fractures created during a field test in overconsolidated glacial drift. Quarterly Journal of Engineering Geology 28, 23-35.

Ó Cofaigh, C. \& Evans, D.J.A. 2001: Sedimentary evidence for deforming bed conditions associated with a grounded Irish Sea glacier, Southern Ireland. Journal of Quaternary Science 16, 435-454.

Passchier, C.W. \& Trouw, R.A.J. 1996: Microtectonics, 289 pp. Springer-Verlag, Berlin, Heidelberg.

Phillips, E.R., Evans, D.J.A. \& Auton, C.A. 2002: Polyphase deformation at an oscillating ice margin following the Loch Lomond Readvance, central Scotland, UK. Sedimentary Geology 149, 157-182.

Phillips, E. \& Merritt, J. 2008: Evidence for multiphase water-escape during rafting of shelly marine sediments at Clava, Inverness-shire, NE Scotland. Quaternary Science Reviews 27, 988-1011.

Piotrowski, J.A. 2006: Groundwater under ice sheets and glaciers. In Knight, P.G. (ed.): Glacier Science and Environmental Change, 50-60. Blackwell, Oxford.

Pollard, D.D. \& Holzhausen, G. 1979: On the mechanical interaction between a fluidfilled fracture and the earth's surface. Tectonophysics 53, 27-57. 
Roberts, D.H., Dackombe, R.V. \& Thomas, G.S.P. 2007: Palaeo-ice streaming in the central sector of the British-Irish Ice Sheet during the Last Glacial Maximum: evidence from the northern Irish Sea Basin. Boreas 36,115-129.

Rijsdijk, K.F., Owen, G., Warren, W.P., McCarroll, D. \& van der Meer, J.J.M. 1999: Clastic dykes in over-consolidated tills: evidence for subglacial hydrofracturing at Killiney Bay, eastern Ireland. Sedimentary Geology 129, 111-126.

Scourse, J.D. \& Furze, M.F.A. 2001: A critical review of the glaciomarine model for Irish Sea deglaciation: evidence from southern Britain, the Celtic shelf and adjacent continental slope. Journal of Quaternary Science 16, 419-434.

\section{Figures}

Figure 1. Map showing location of the Meads of St. John study area. Also shown is the generalised ice movement directions within the Moray Firth Ice Stream and ice flowing across Lochindorb and down the valley of the River Findhorn.

Figure 2. A. Well-bedded, fluviatile sandstones and conglomerates of the Kingsteps Sandstone Formation, Middle to Upper Devonian Forres Sandstone Group (Upper Old Red Sandstone facies). B. and C. Complex, cross-cutting sand, silt and clay-filled hydrofractures developed within thinly bedded sandstones and siltstones. The numbers 1 (oldest) to 5 (youngest) record the relative ages of the various parts of the hydrofracture system based upon the cross-cutting relationships displayed between these structures. D. Overview of part of the Meads of St. John hydrofracture system showing the location of the 10 samples (N12282 to N12291) collected for micromorphological analysis.

Figure 3. Diagram and photomontage showing the details of part of the Meads of St John hydrofracture system.

Figure 4. Lower hemisphere stereographic projections showing: A. dip and dip direction data obtained for the Meads of St. John hydrofracture system and bedding in the surrounding Middle to Upper Devonian sandstone bedrock; and B. dip and dip direction data obtained for bedding and joints from a nearby bedrock outcrop which is unaffected by hydrofracturing.

Figure 5. Annotated scan and interpretation of sample N12282. This thin section is taken from a bedding-parallel, sill-like section of the Meads of St. John hydrofracture system (see Fig. 2D) and shows the relationships between the earlier formed laminated silt and clay Phase 1 fill and later, more thickly laminated sand and silt Phase 2 fill (see text for details). Both of these earlier formed fills and bedrock are cut by veins of the massive sands which characterise the Phase 3 fill.

Figure 6. Annotated scan and interpretation of sample N12283. This thin section is taken from a gently inclined, bedding-parallel section of the Meads of St. John hydrofracture system (see Fig. 2D) which cross-cuts, at a very low-angle, bedding in the adjacent sandstone bedrock. The thin section also shows the relationships between the earlier formed laminated silt and clay Phase 1 fill and later, more thickly laminated sand and silt Phase 2 fill. In this sample the lamination within silt and clay has been disrupted prior to the injection of the Phase 2 sandy fill. The fine-scale 
lamination and cross-lamination within the thicker sand laminae of the Phase 2 fill is deformed by a convolute style folds (see text for details).

Figure 7. Annotated scan and interpretation of sample N12291. This thin section is taken from a bedding-parallel section located towards the top of the Meads of St. John hydrofracture system (see Fig. 2D). The thin section also shows the relationships between the earlier formed laminated silt and clay Phase 1 fill and later, more thickly laminated sand and silt Phase 2 fill. In this sample the lamination within silt and clay has been disrupted prior to the injection of the Phase 2 sandy fill. The fine-scale lamination within the Phase 1 fill is deformed by a number of convolute-style folds and low-angle extensional shears (see text for details).

Figure 8. A. Highly disrupted laminated silts and clay-rich fill (Phase 1 fill) formed adjacent to the lower margin of a sill-like section of the Meads of St. John hydrofracture (Sample N12283, plane polarised light). B. Highly disrupted laminated silts and clay-rich fill (Phase 1 fill) deformed by small-scale, disharmonic convolutestyle folds and low-angle, SE-directed extensional shears (Sample N12291, plane polarised light).

Figure 9. Annotated scan and interpretation of sample N12284. This thin section is taken from close to the intersection between one of the sill-like main feeder conduits to the Meads of St. John hydrofracture system and a steeply inclined dyke section (see Fig. 2D). The thin section also shows the complex relationships between the earlier formed laminated silt and clay Phase 1 fill and later, more thickly laminated sand and silt Phase 2 fill. Borth of these earlier stages of sediment-fill are cross-cut and truncated against or pass laterally into the homogenised silts and sands which characterise the Phase 3 fill (see text for details).

Figure 10. Annotated scan and interpretation of sample N12286. This thin section is taken from the upper part of a steeply inclined, transgressive dyke-like section of the Meads of St. John hydrofracture system (see Fig. 2D). The thin section shows the disruption of the earlier formed Phase 1 and 2 fills during the repeated phases of opening of this hydrofracture. The lamination within a wedge-shaped plug of Phase 2 sand and silt fill which occupied the lower part of the steeply inclined section of the hydrofracture is off-set by a number of small-scale normal faults (see text for details). In the upper part of the hydrofracture, the sediment-fill enclosed several rounded blocks of sandstone detached from the adjacent wall-rock.

Figure 11. Annotated scan and interpretation of sample N12288. This thin section is taken from the upper part of a steeply inclined, transgressive dyke-like section of the Meads of St. John hydrofracture system (see Fig. 2D). The thin section shows the disruption of the earlier formed Phase 1 and 2 fills during the repeated phases of opening of this hydrofracture (see text for details).

Figure 12. Annotated scan and interpretation of sample N12285. This thin section is taken from close to the southern margin of a steeply inclined, transgressive dyke-like section of the Meads of St. John hydrofracture system (see Fig. 2D). The thin section is dominated by the sandstone wall-rock and shows how the massive Phase 3 sandy fill has partially replaced the bedrock (see text for details). 
Figure 13. Annotated scan and interpretation of sample N12287. This thin section is taken from within one of the irregular, apparently late stage subvertical fissures filled by massive to highly disrupted sand, silt and clay (see Fig. 2D). The thin section shows the highly complex, disrupted nature of the sediment filling these late stage fissures with the fill being dominated by the homogenised sands and silts characteristic of Phase 3 fill (see text for details).

Figure 14. Annotated scan and interpretation of sample N12289. This thin section is taken from within one of the irregular, apparently late stage subvertical fissures filled by massive to highly disrupted sand, silt and clay (see Fig. 2D). The thin section shows the highly complex, disrupted nature of the sediment filling these late stage fissures with the fill being dominated by the homogenised sands and silts characteristic of Phase 3 fill. The laminated silts and sands of the Phase 2 fill preserved on the north-western side of the hydrofracture are deformed by a number of northerly dipping normal faults. These faults are very poorly developed within the adjacent Phase 3 fill indicating that faulting occurred prior to the introduction of the bulk of the Phase 3 fill (see text for details).

Figure 15. Annotated scan and interpretation of sample N12290. This thin section is taken from within one of the irregular, apparently late stage subvertical fissures filled by massive to highly disrupted sand, silt and clay (see Fig. 2D). The thin section shows the highly complex, disrupted nature of the sediment filling these late stage fissures with the fill being dominated by the homogenised sands and silts characteristic of Phase 3 fill (see text for details).

Figure 16. Diagram showing the position of the thin sections (N12282 to N12291) within the Meads of St. John hydrofracture system.

Figure 17. Microscale graphic logs of measured sections through the least disturbed parts of the Meads of St. John hydrofracture system. A. N12282. B. N12283. C. N12291. D. N12284. E. N12286. F. N12288.

Figure 18. Diagram showing the idealised fluctuation in meltwater overpressure during hydrofracturing. A. Single flow event showing the relationships between change in overpressure hydrofracture propagation and sediment fill. B. Multiple flow events showing decreasing maximum values of overpressure with time. C. Increase in fluid overpressure relating to the reactivation of the hydrofracture and/or fracturing of the adjacent wall-rock and 'break out' of fluidised sediment.

Figure 19. Diagram summarising the range of microstructures and relationships between the three phases of sediment fill present within the bedding-parallel sill-like sections of the Meads of St John hydrofracture system.

Figure 20. A. Diagram summarising the range of cross-cutting relationships displayed between the dyke and sill-like sections of the Meads of St. John hydrofracture system. These relationships allow the relative age of the different parts of the system to be established. B. Diagrams showing the relative sense of movement across the different parts of the hydrofracture system showing that the bedrock is undergoing overall extension during hydrofracturing with the introduction of the sediment fill leading to an overall increase in volume. 
Figure 21. Schematic diagram showing the overall evolution of the Meads of St. John hydrofracture system.

Figure 22. Schematic diagram showing the potential link between the evolution of the Meads of St. John hydrofracture system and the retreat of the Findhorn glacier. 


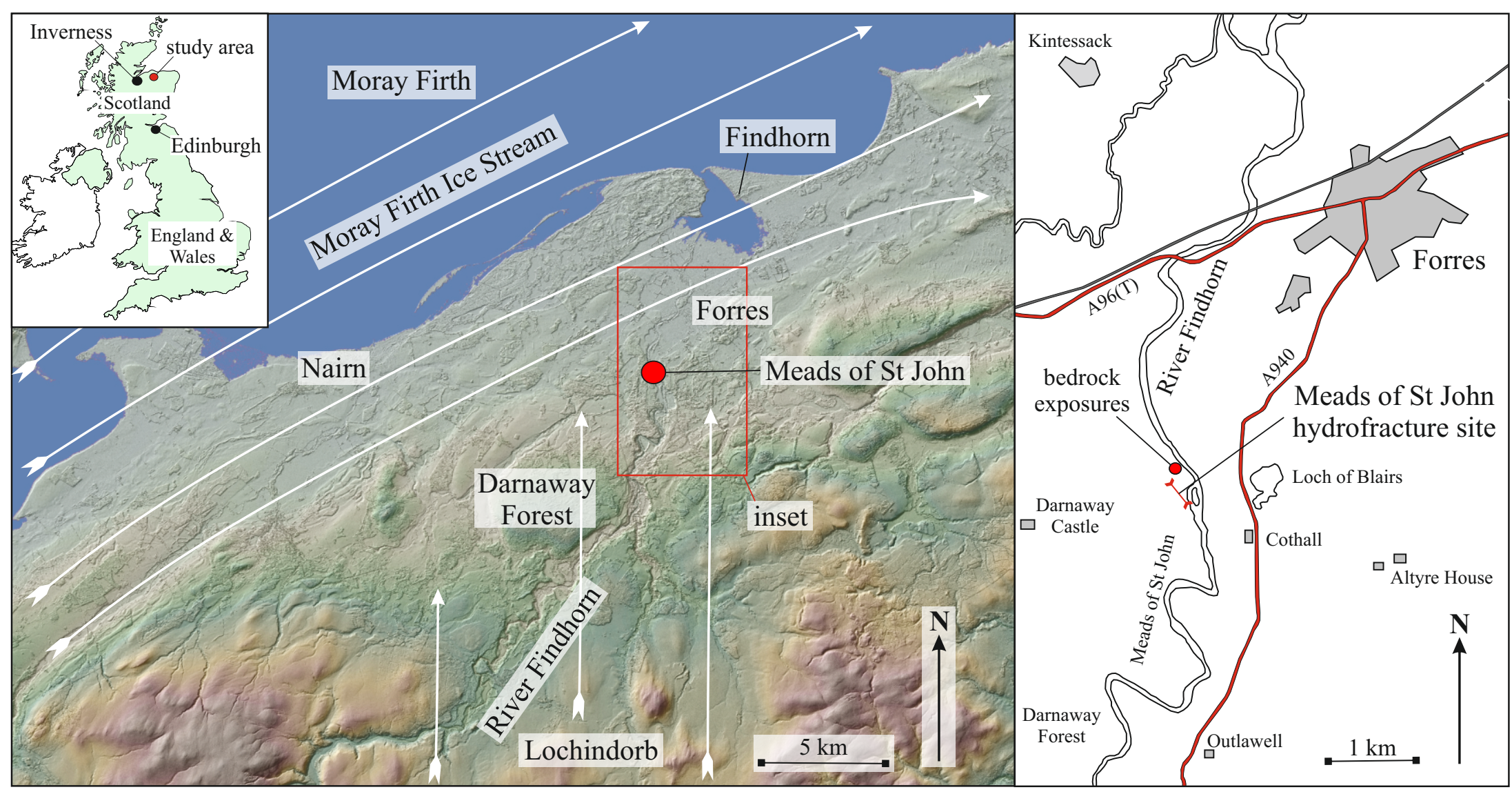

$\longrightarrow$ ice movement direction 

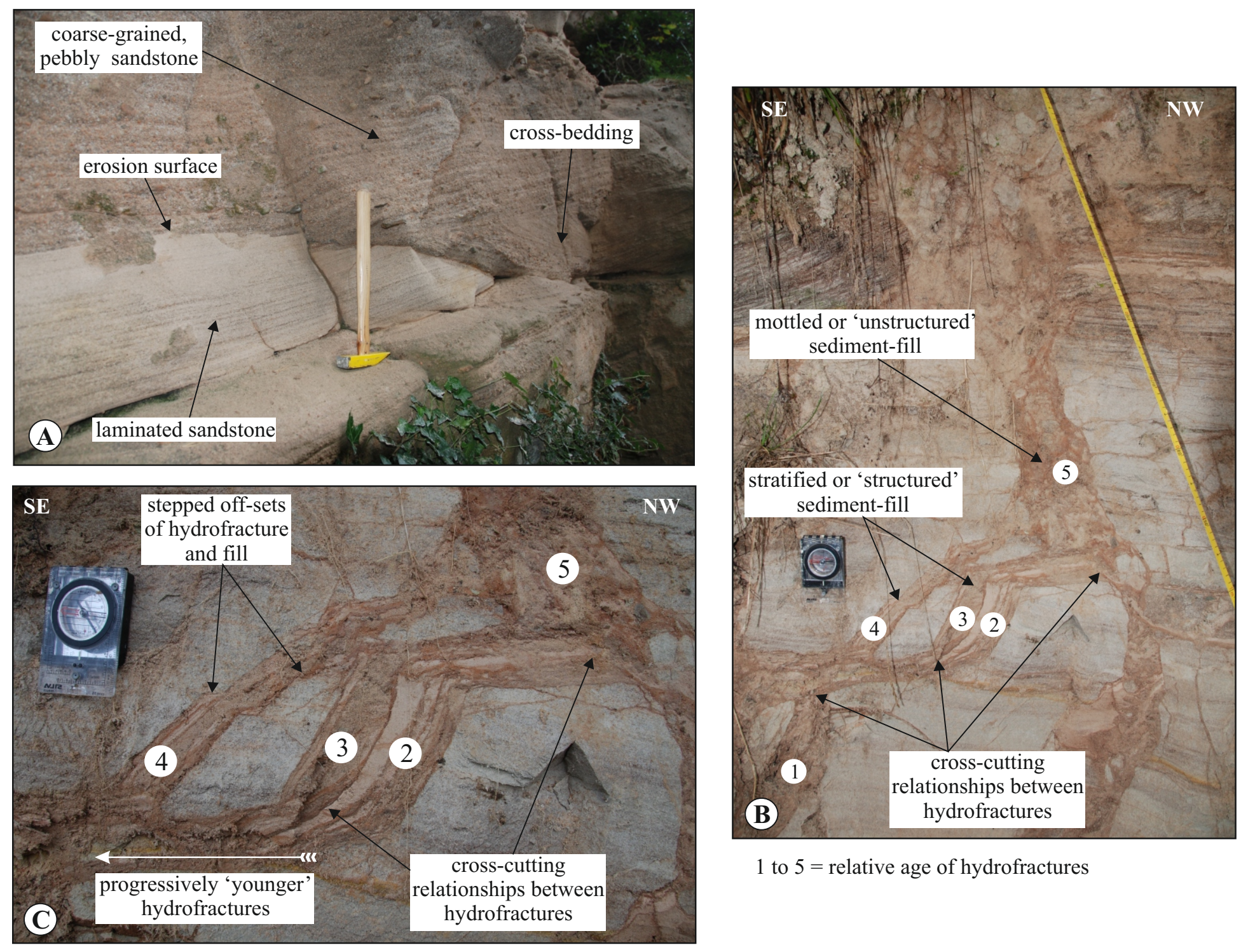

1 to $5=$ relative age of hydrofractures

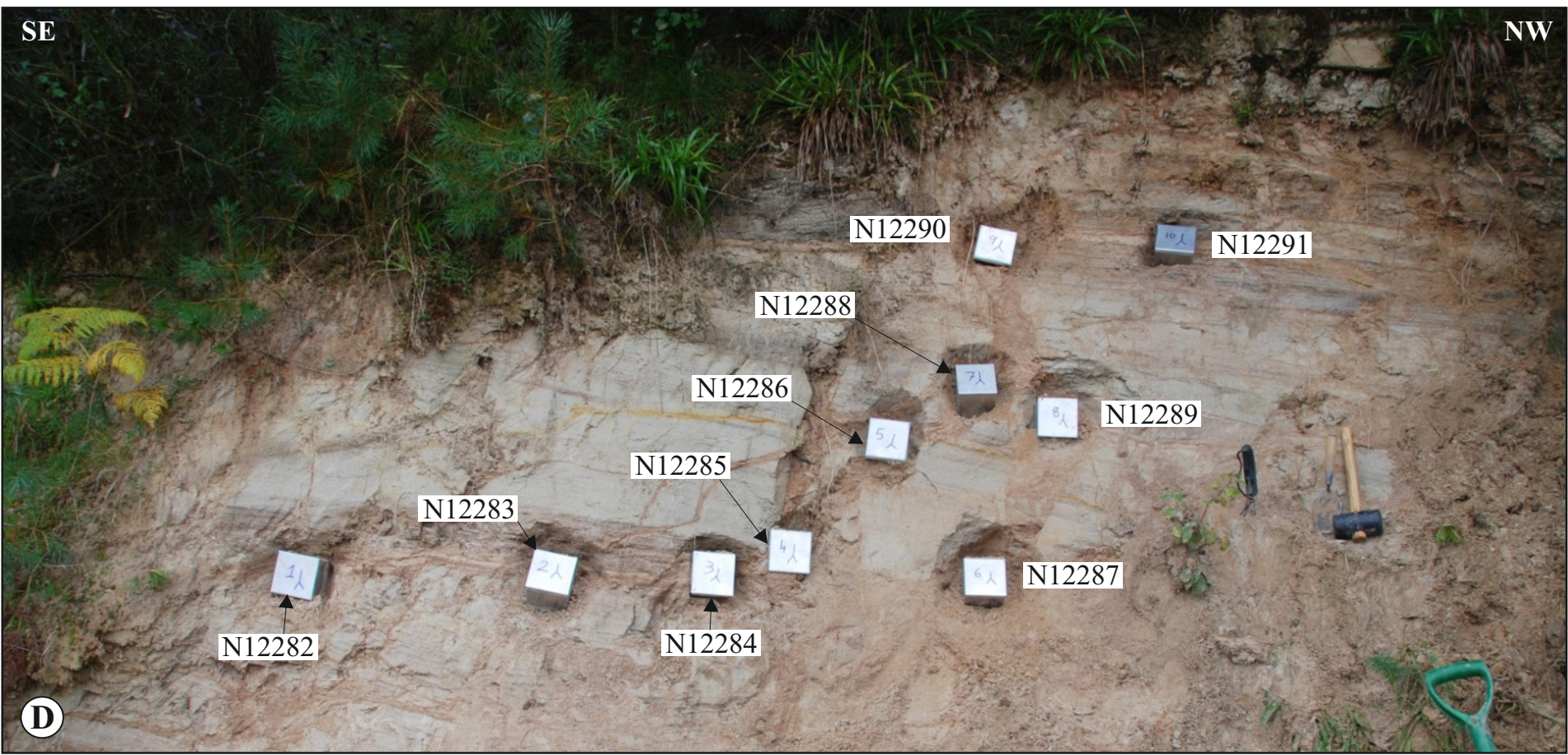




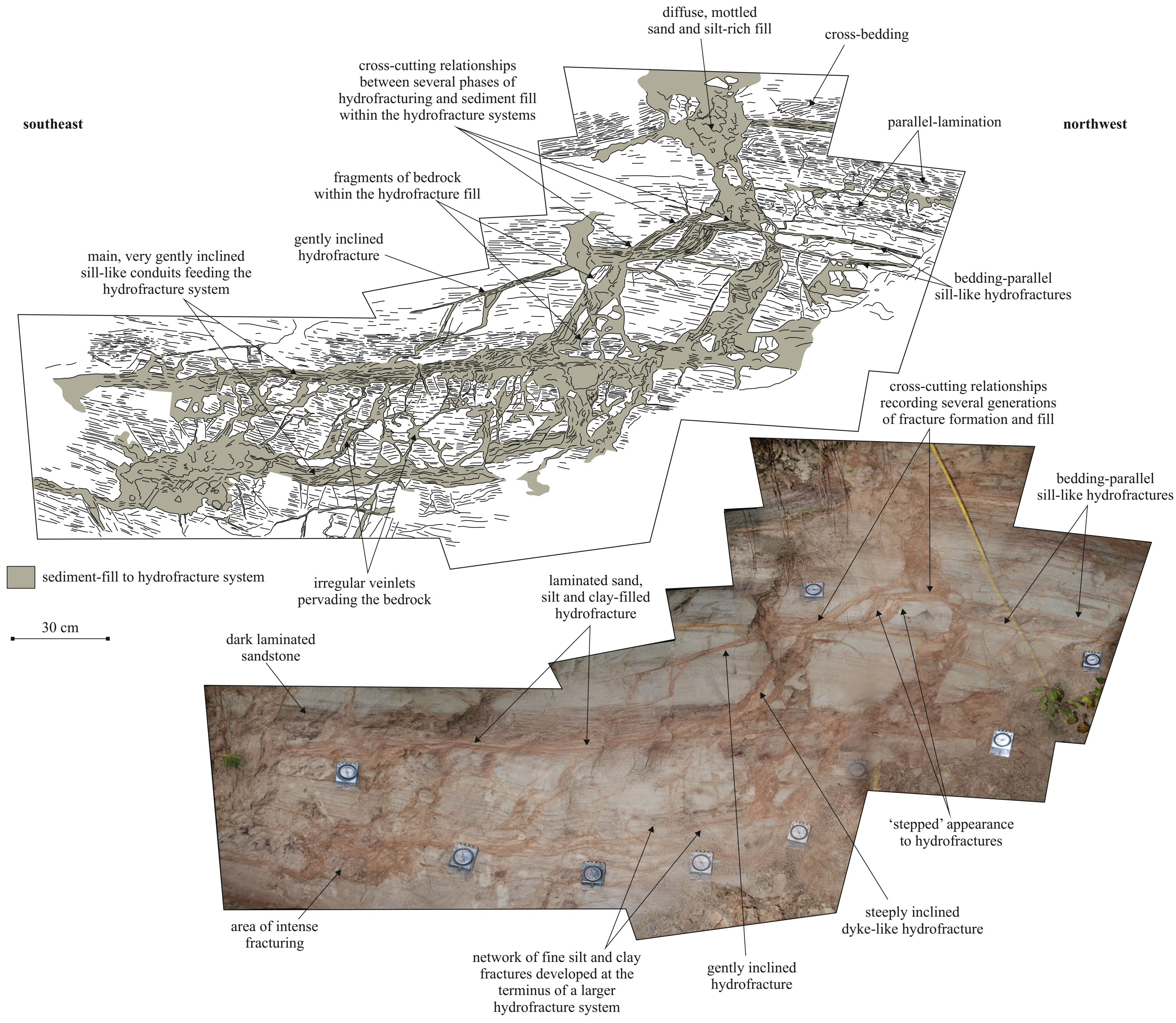




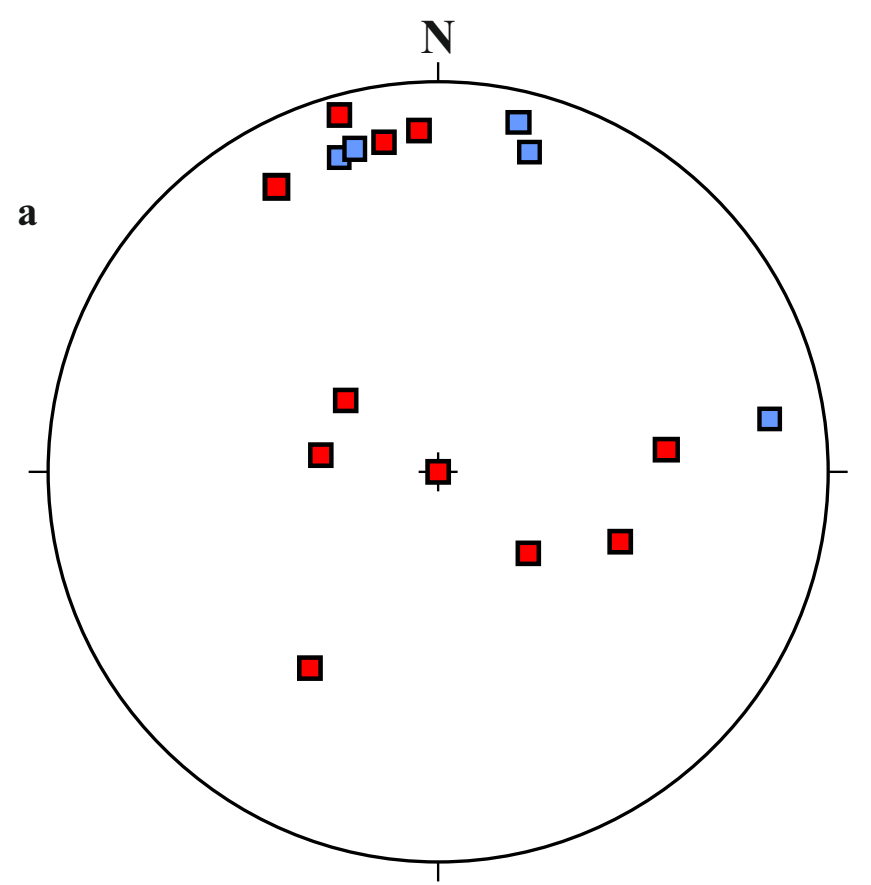

$\square$ hydrofractures $(\mathrm{N}=13)$

$\square$ bedding $(\mathrm{N}=5)$

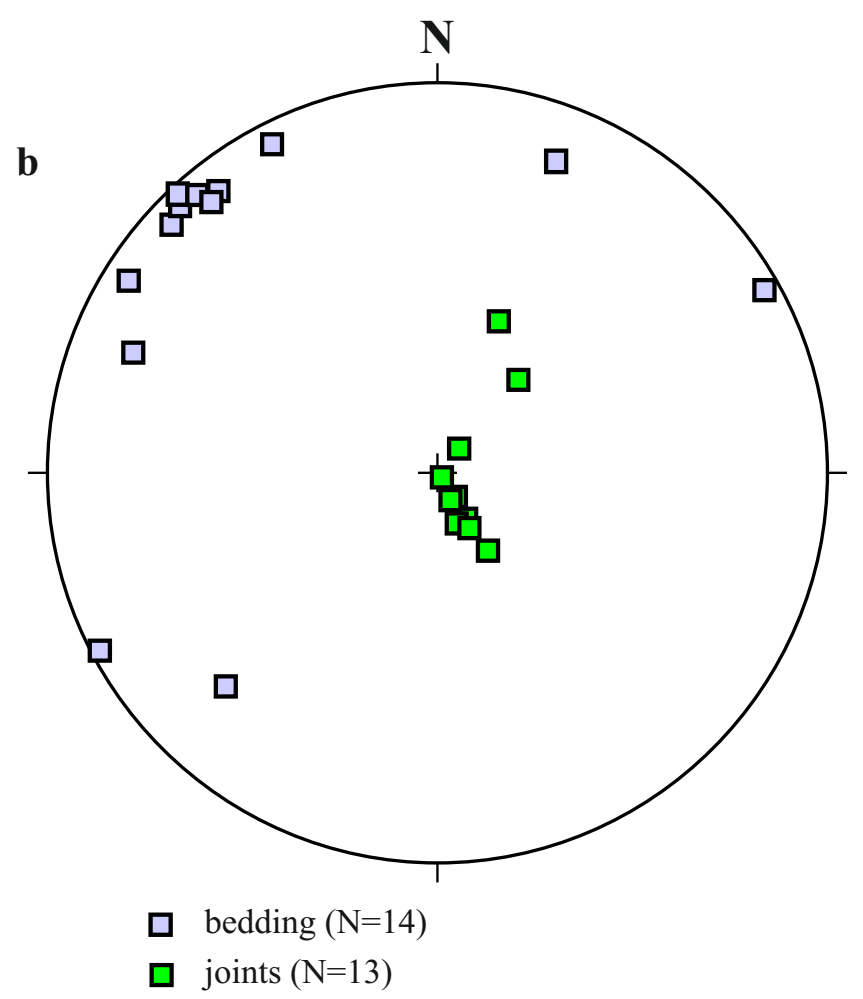

Figure 4 


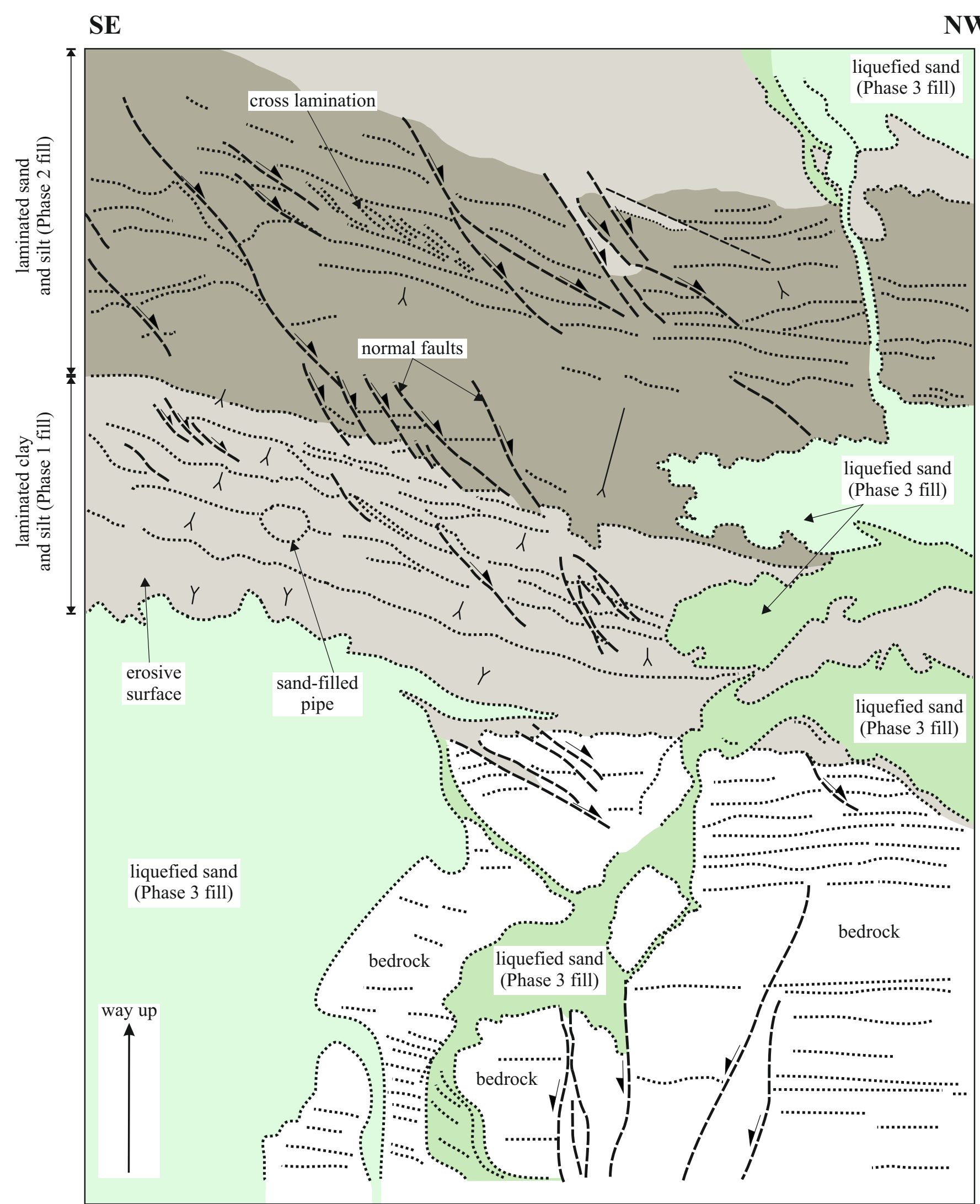

Sample N12282: Meads of St. John, hydrofracture

$10 \mathrm{~mm}$

Phase3 liquefied sand

$\square$ Phase 3 liquefied sand

$\square$ Phase 2 laminated sand and silt

$\square$ Phase 1 laminated clay, silt and sand
SE

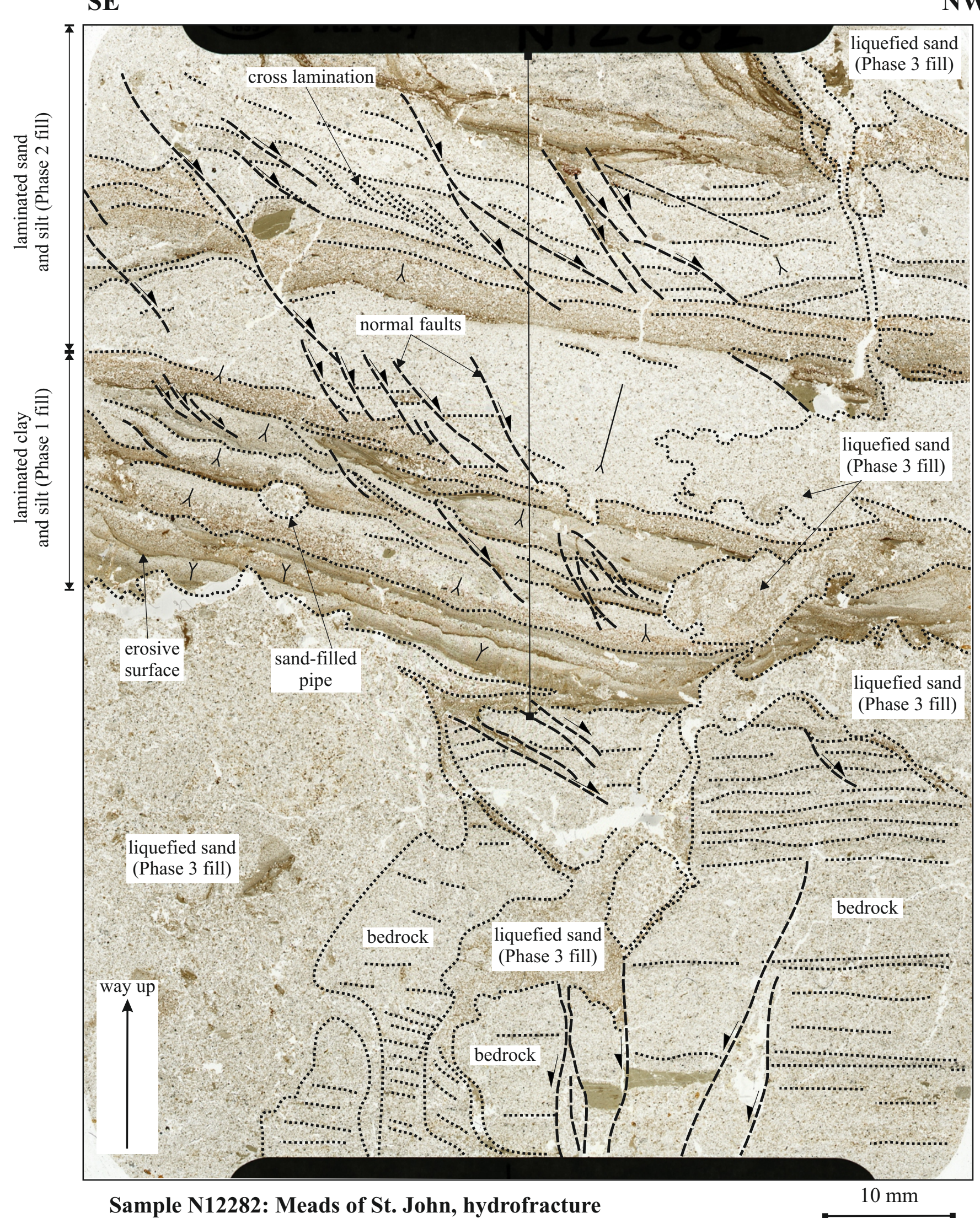

- sense of displacement on faults and shears

-...- faults

5. bedding/layering/lamination

— line of measured section (see Fig. 17) 

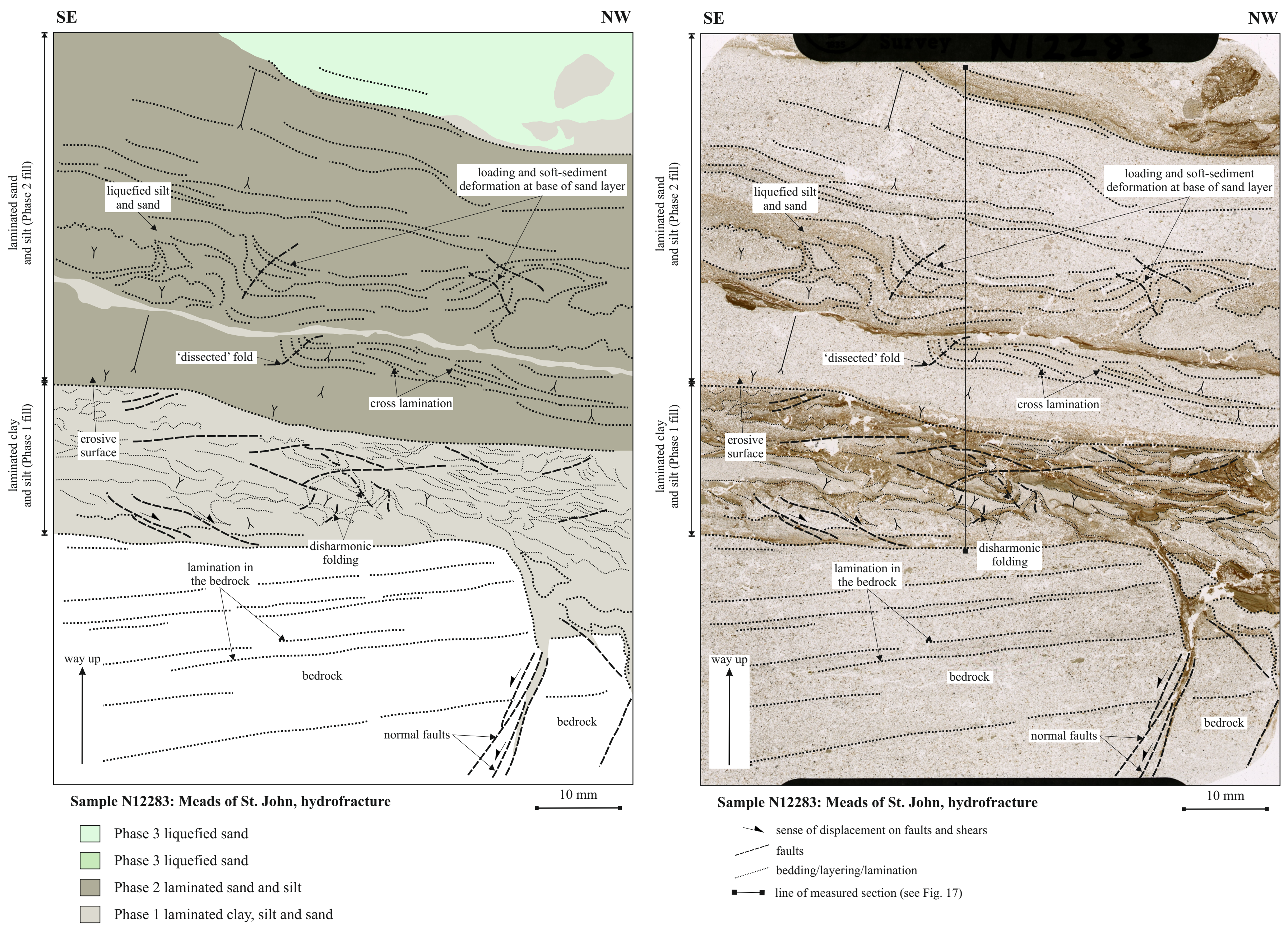

Sample N12283: Meads of St. John, hydrofracture

- sense of displacement on faults and shears

-..- faults

- bedding/layering/lamination

- line of measured section (see Fig. 17) 


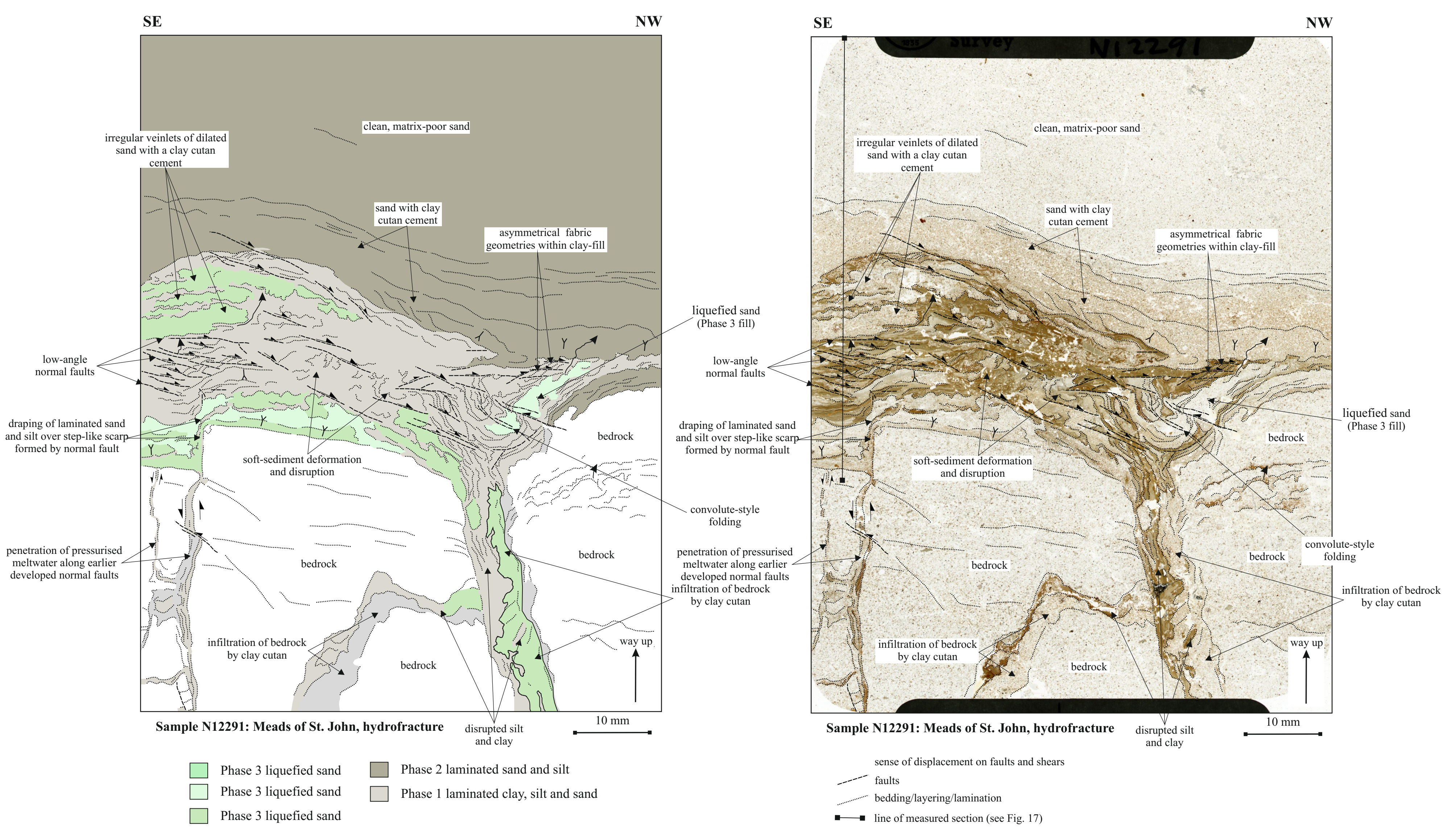

Figure 7 

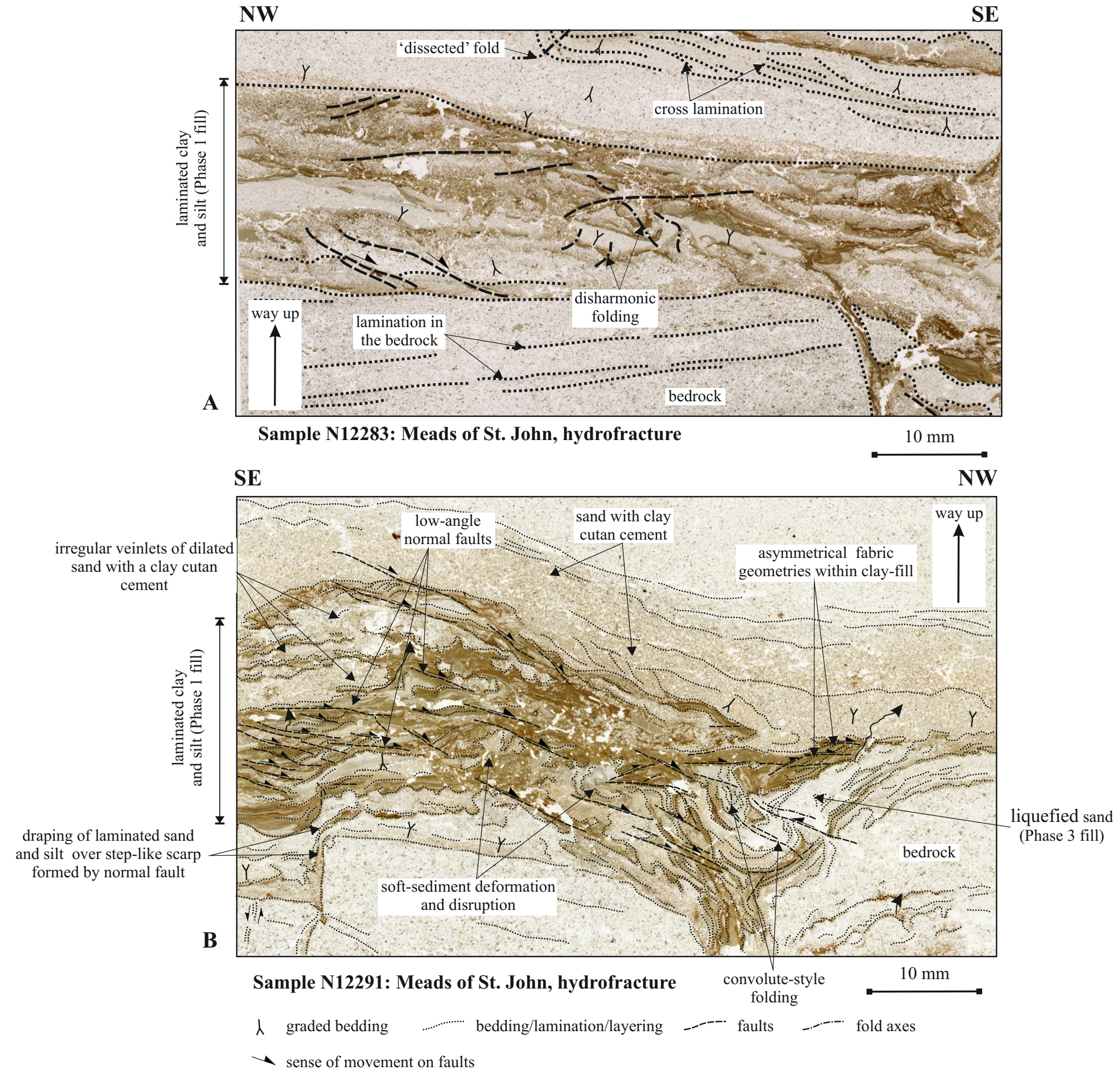

Figure 8 


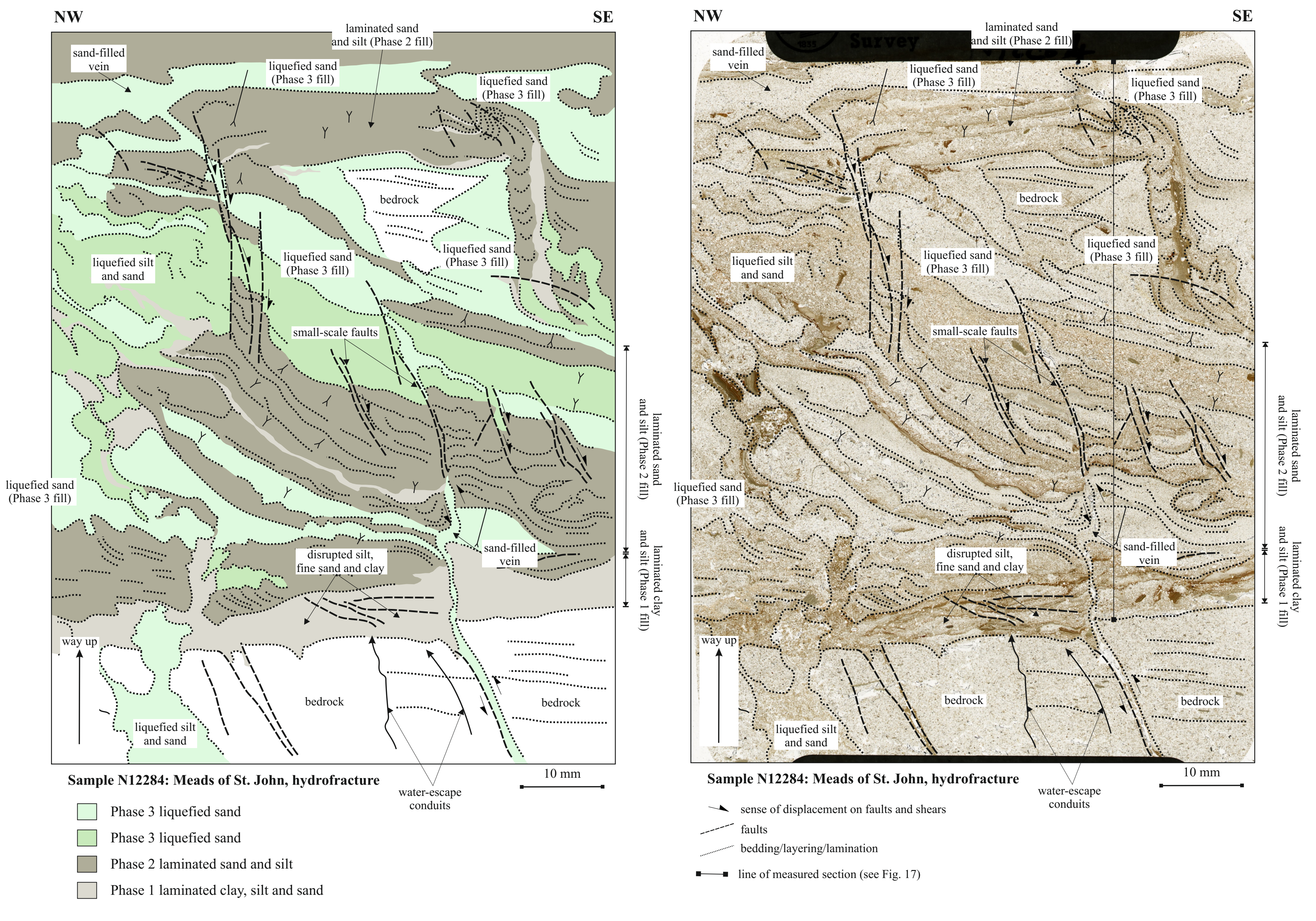

Figure 9 
SE

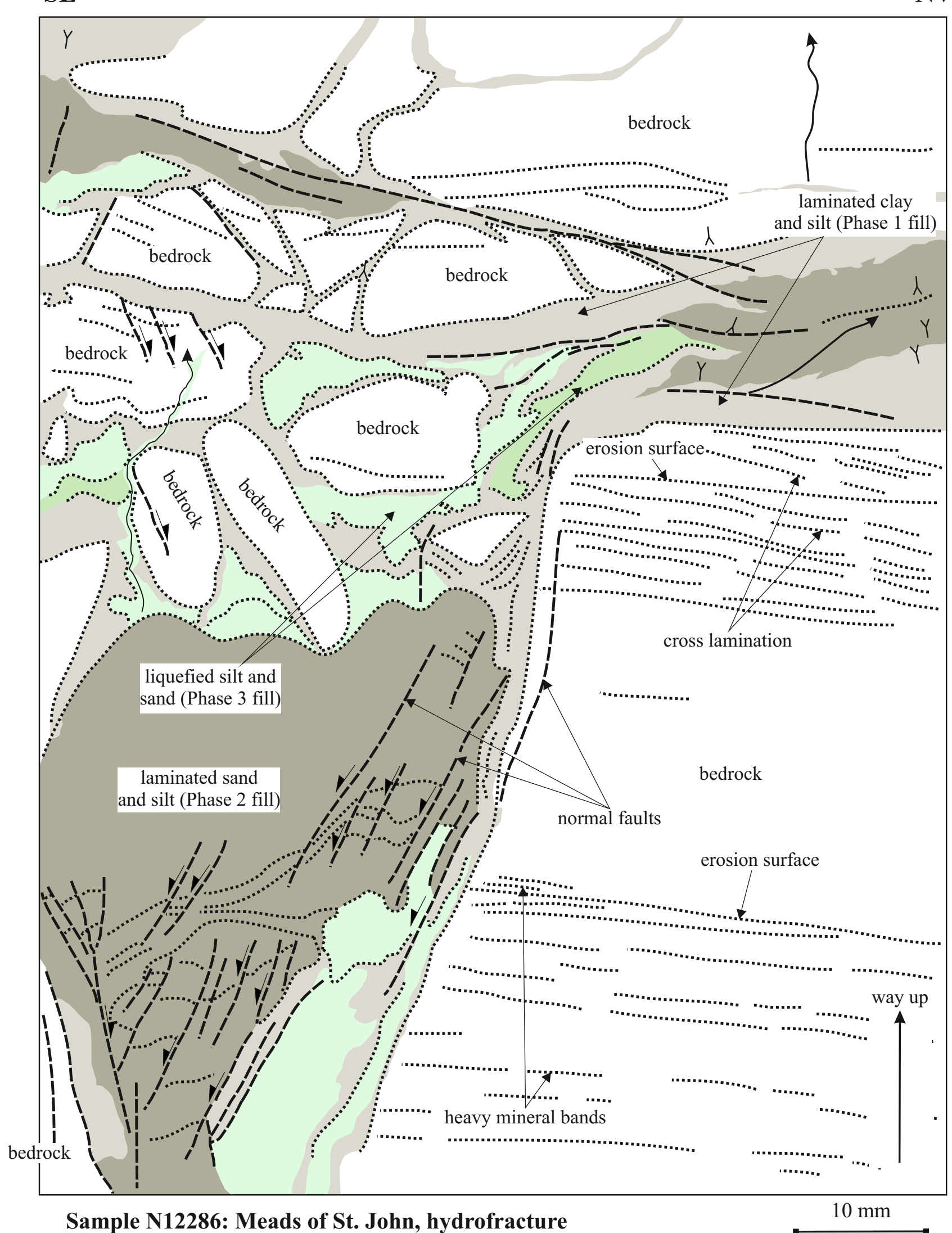

Sample N12286: Meads of St. John, hydrofracture

$\square$ Phase 3 liquefied sand

$\square$ Phase 3 liquefied sand

$\square \quad$ Phase 2 laminated sand and silt

$\square$ Phase 1 laminated clay, silt and sand

Figure 10
NW

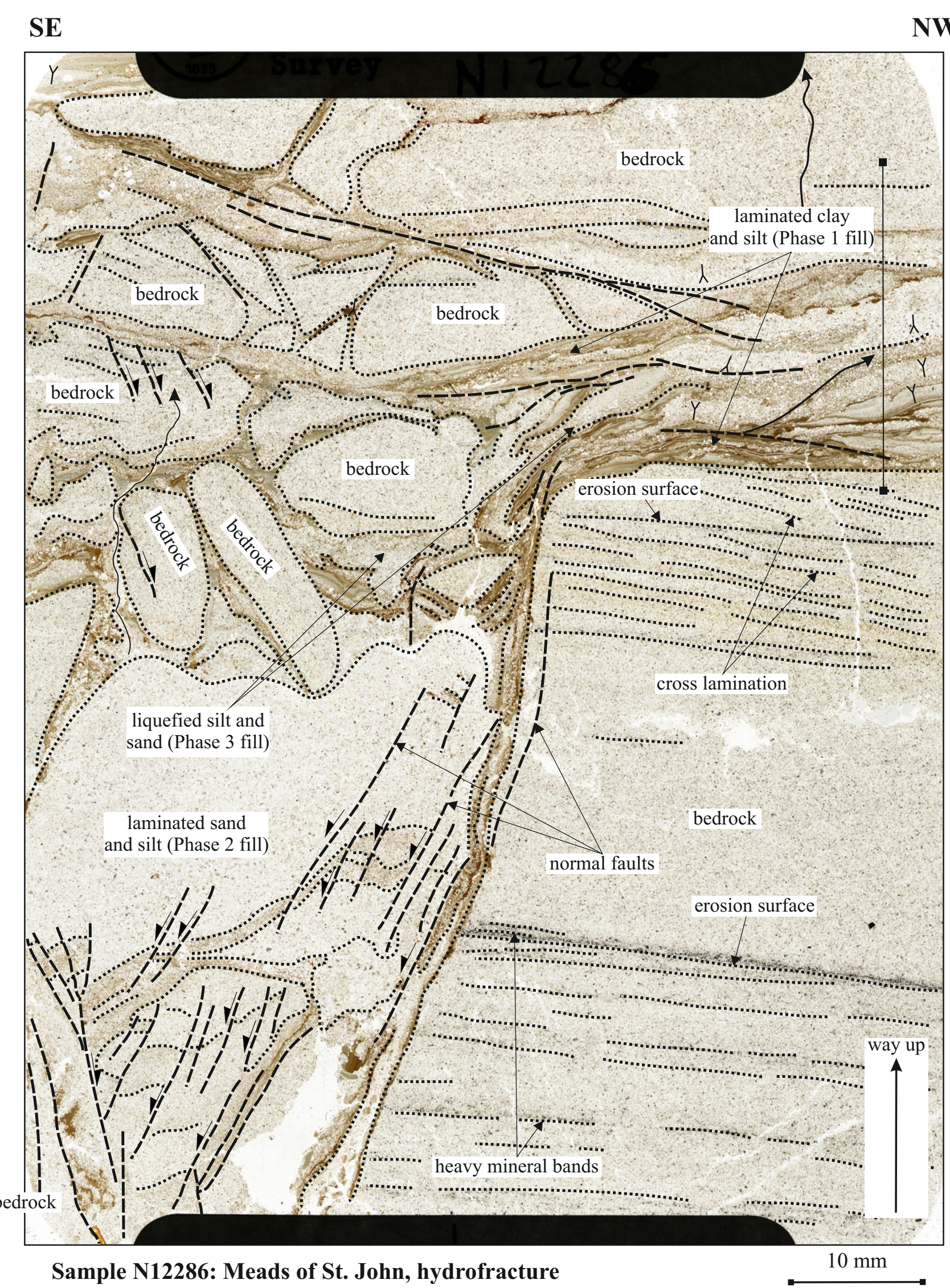

- sense of displacement on faults and shears

-...- faults

bedding/layering/lamination

- line of measured section (see Fig. 17) 


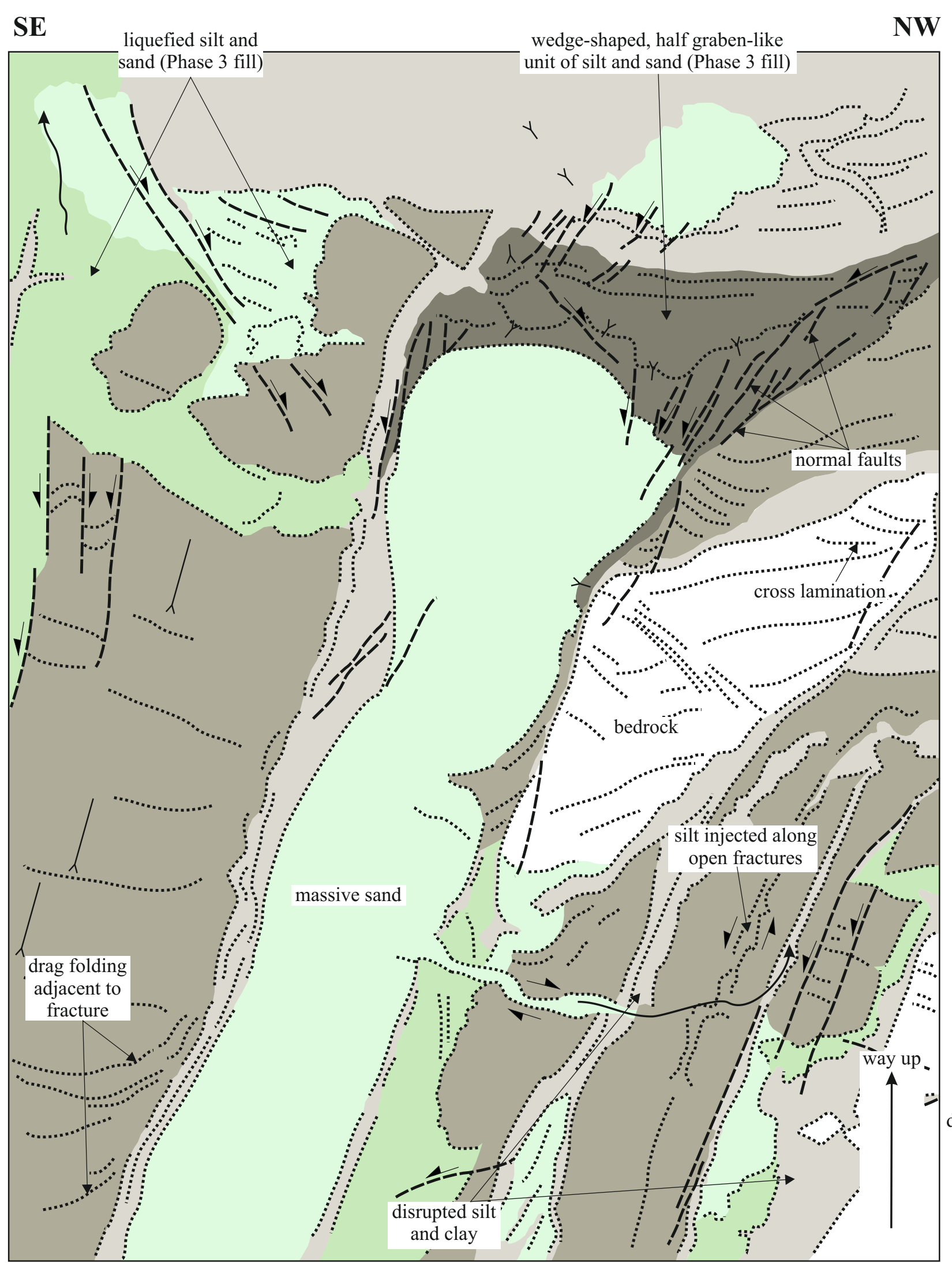

Sample N12288: Meads of St. John, hydrofracture

$10 \mathrm{~mm}$

$\square$ Phase 3 liquefied san

$\square$ Phase 3 liquefied sand

$\square$ Phase 3 liquefied sand

Phase 2 laminated sand and silt

$\square$ Phase 2 laminated sand and silt

$\square$ Phase 1 laminated clay, silt and sand

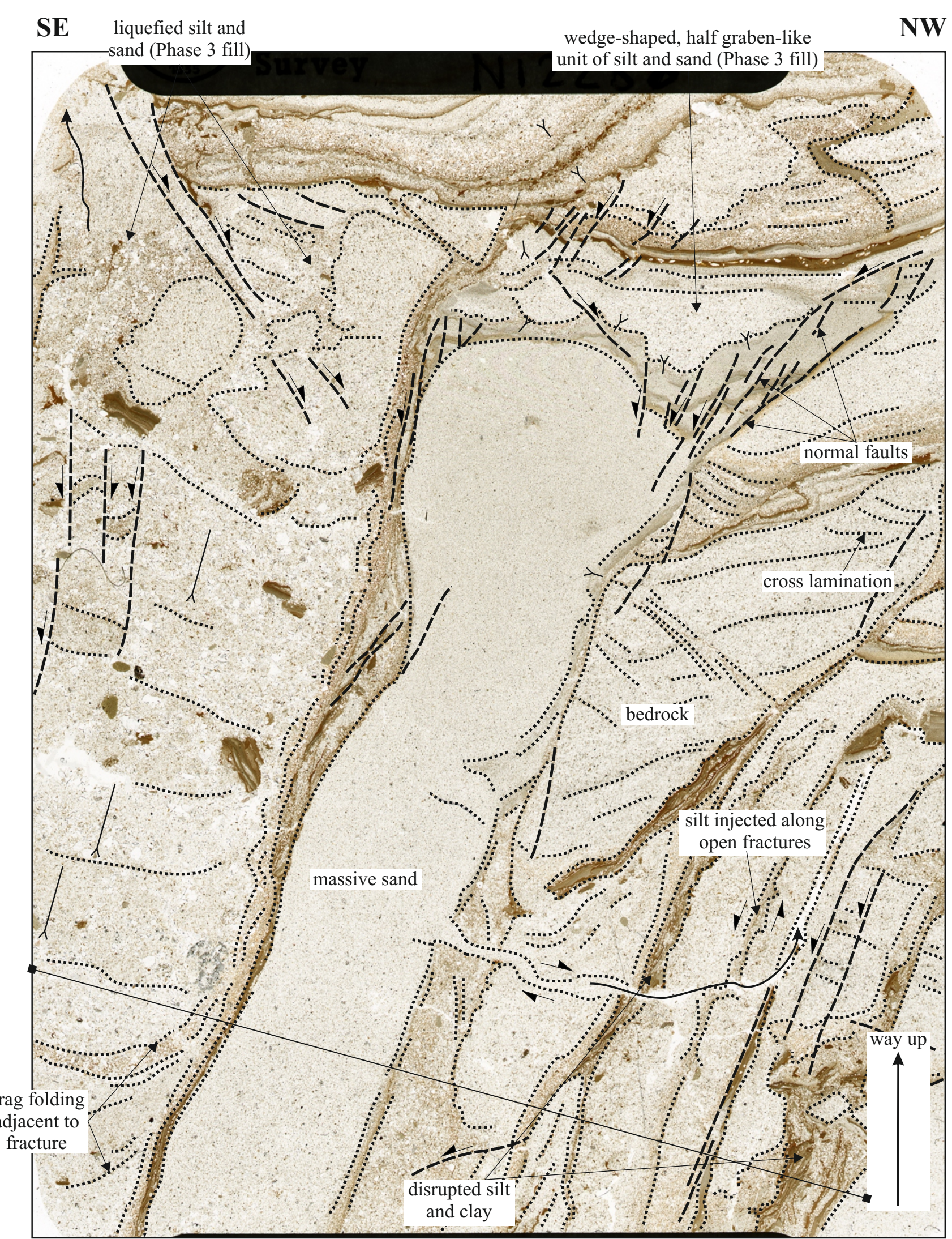

Sample N12288: Meads of St. John, hydrofracture

$10 \mathrm{~mm}$

-...- faults

. bedding/layering/lamination

— line of measured section (see Fig. 17) 

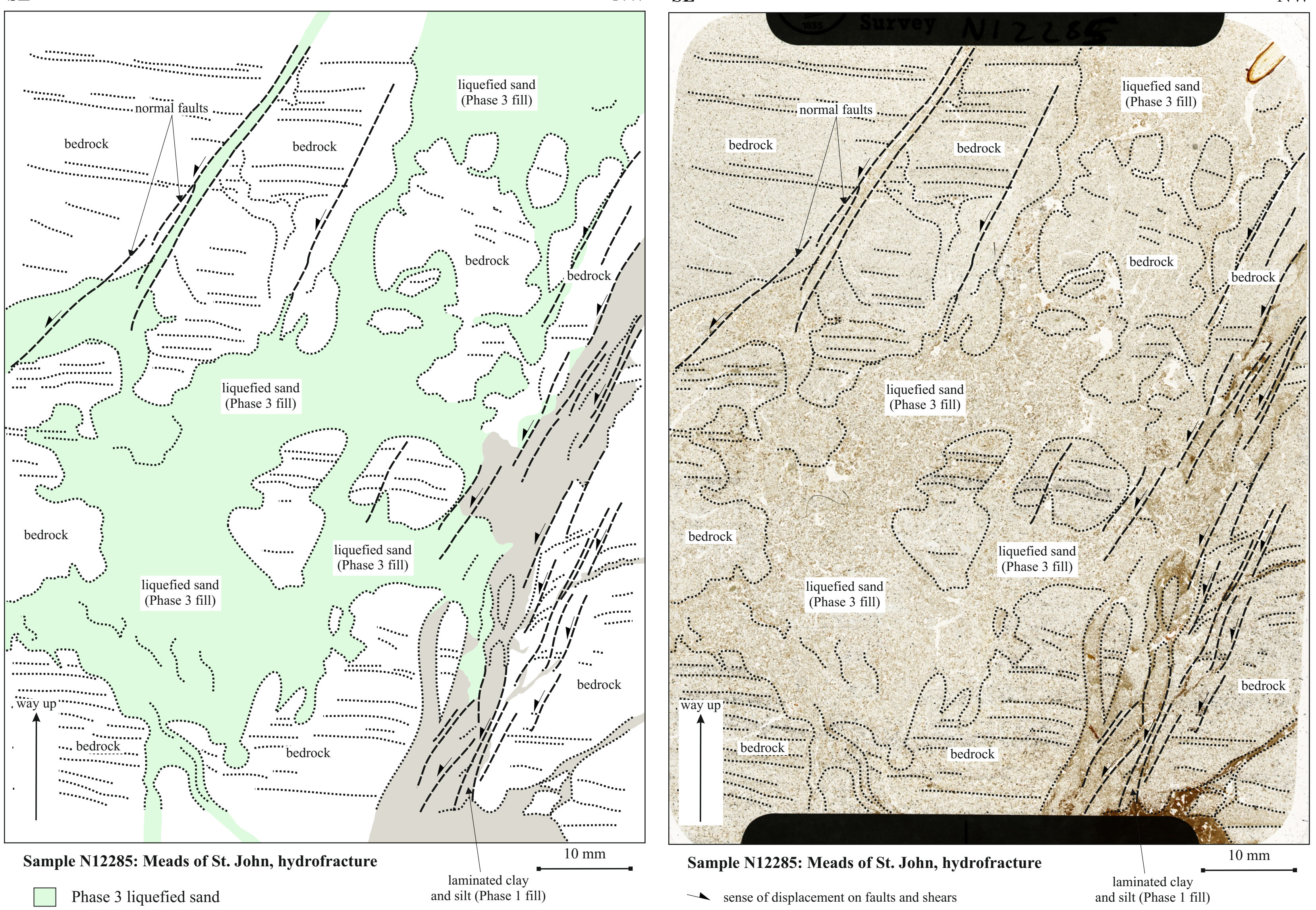

Sample N12285: Meads of St. John, hydrofracture

$10 \mathrm{~mm}$

Phase 3 liquefied sand

- sense of displacement on faults and shears

d silt (Phase 1

$\square$ Phase 1 laminated clay, silt and sand

-...- faults

bedding/layering/lamination

Figure 12 
NW

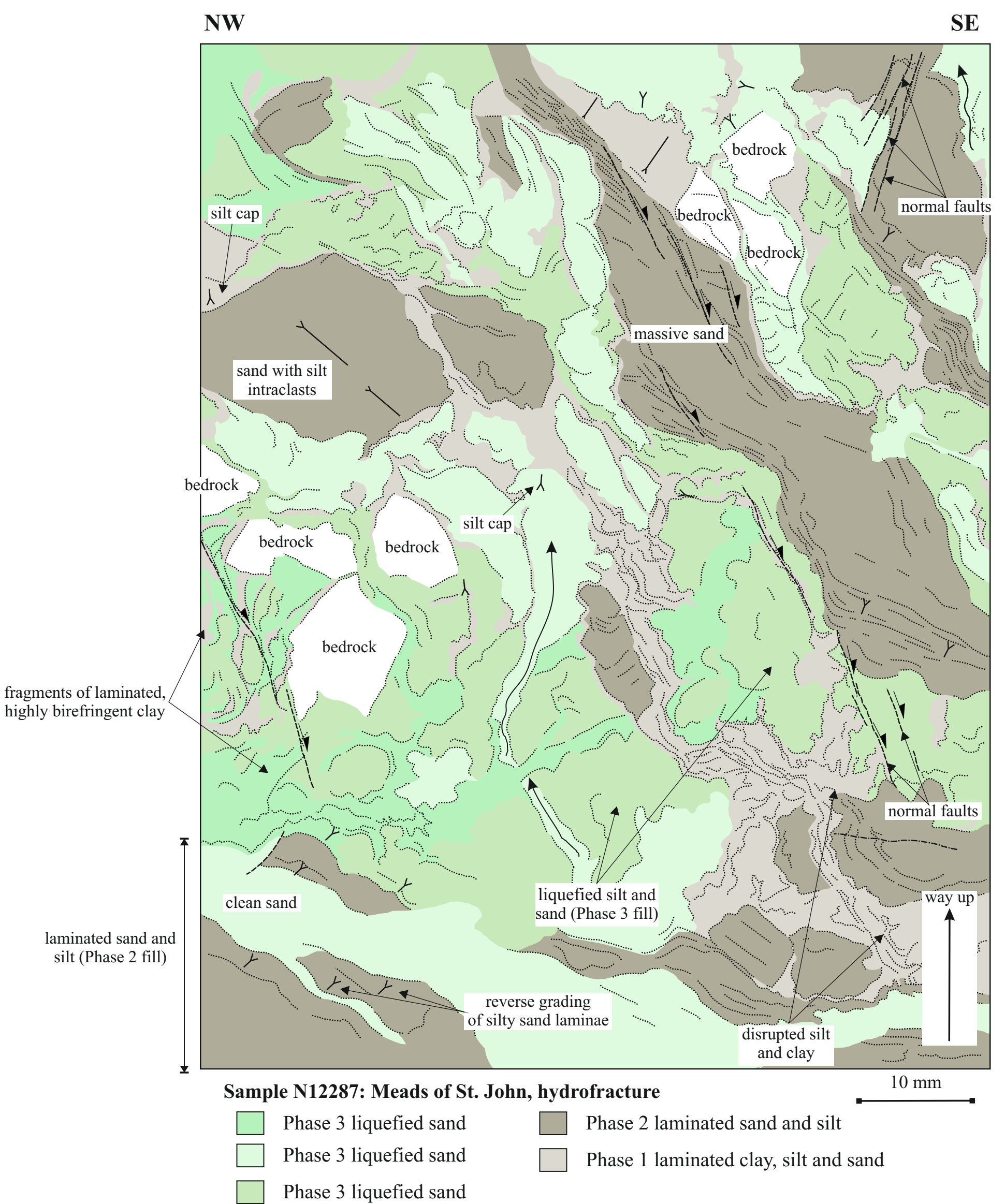

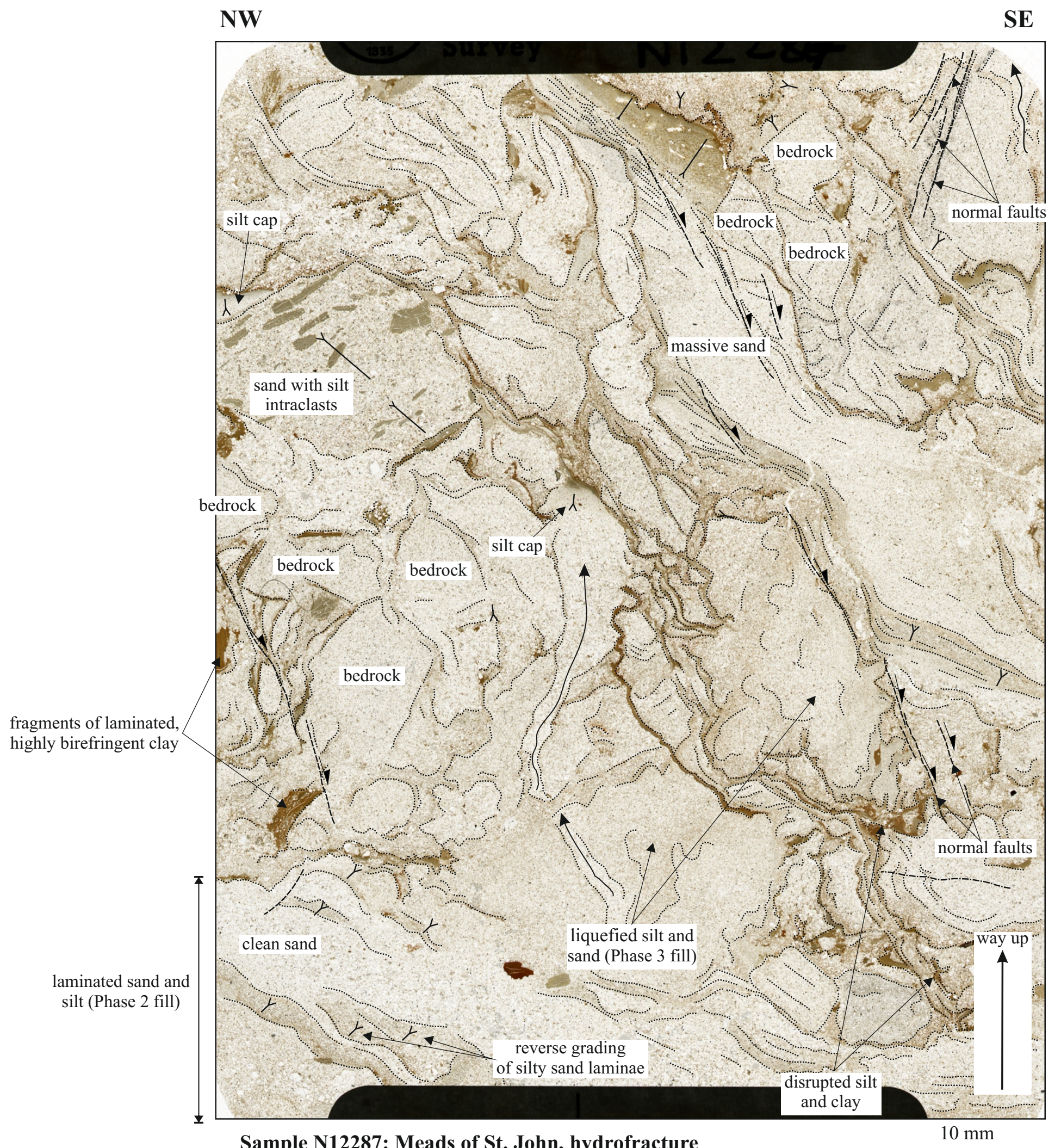

Sample N12287: Meads of St. John, hydrofracture

- sense of displacement on faults and shears

-...- faults

bedding/layering/lamination

Figure 13 


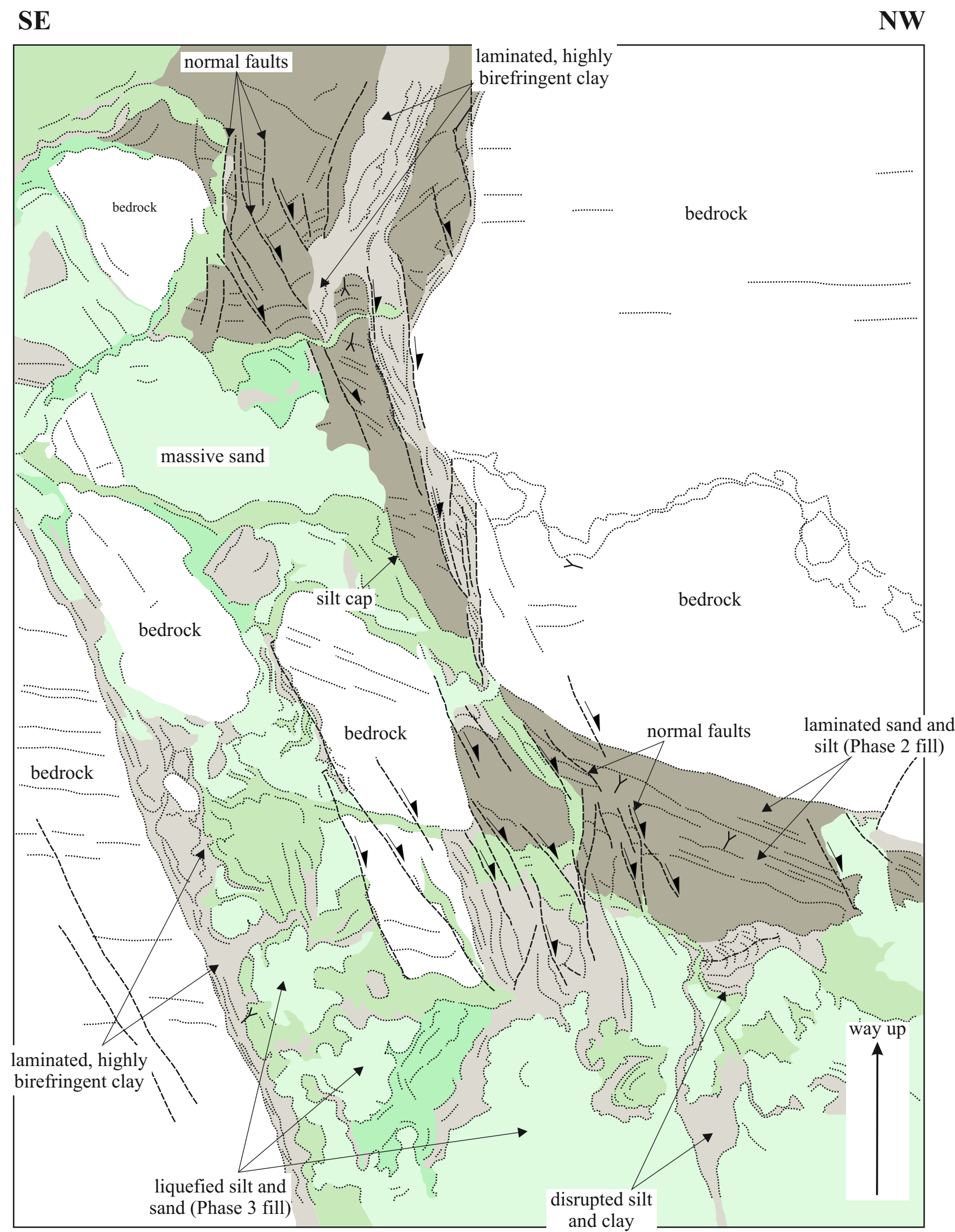

Sample N12289: Meads of St. John, hydrofracture

$10 \mathrm{~mm}$

$\square \quad$ Phase 3 liquefied sand

$\square$ Phase 3 liquefied sand

$\square$ Phase 3 liquefied sand

Phase 2 laminated sand and silt

Phase 2 laminated sand and silt

Phase 1 laminated clay, silt and sand

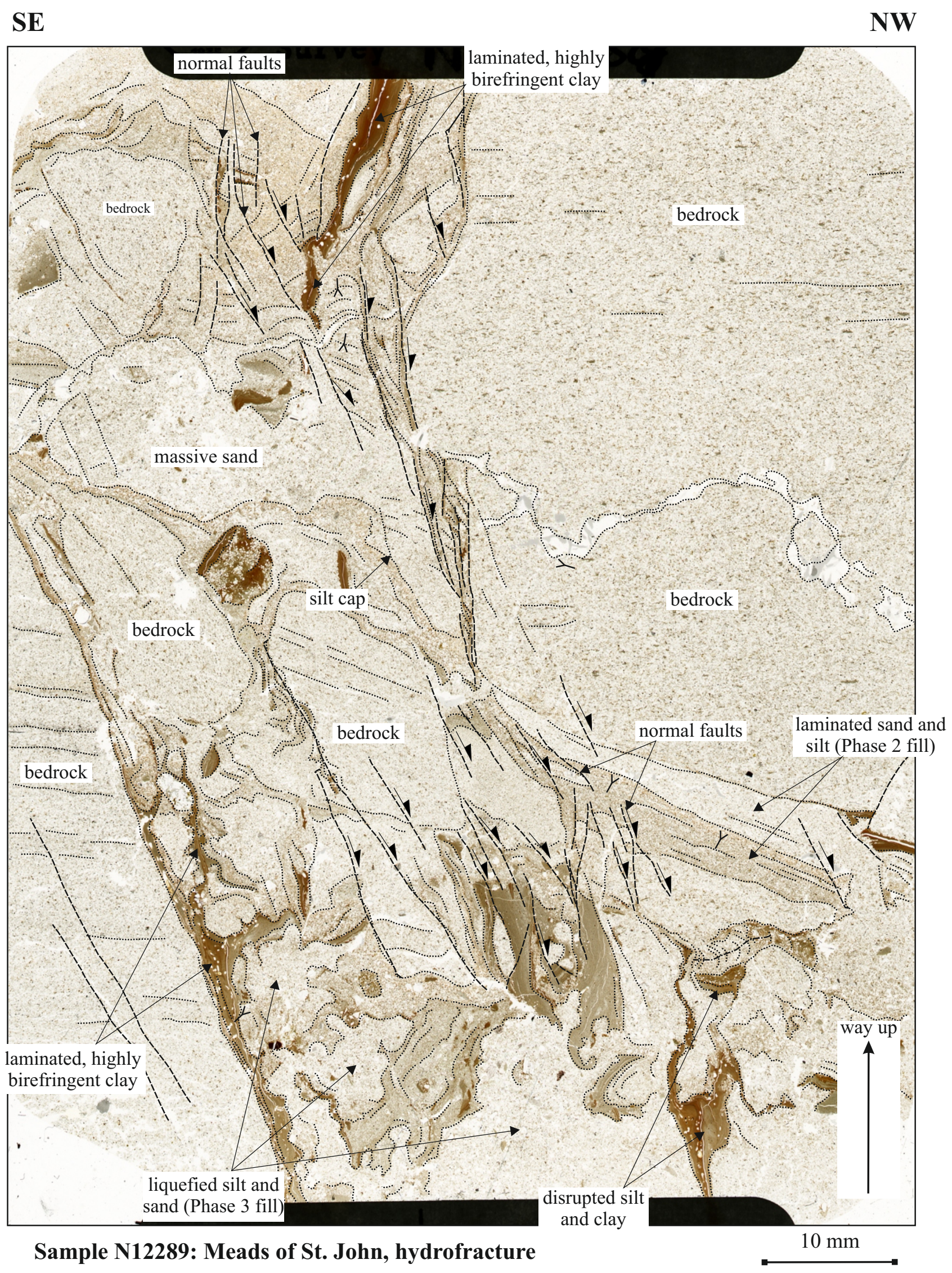

- sense of displacement on faults and shears

-..- faults

bedding/layering/lamination

Figure 14 


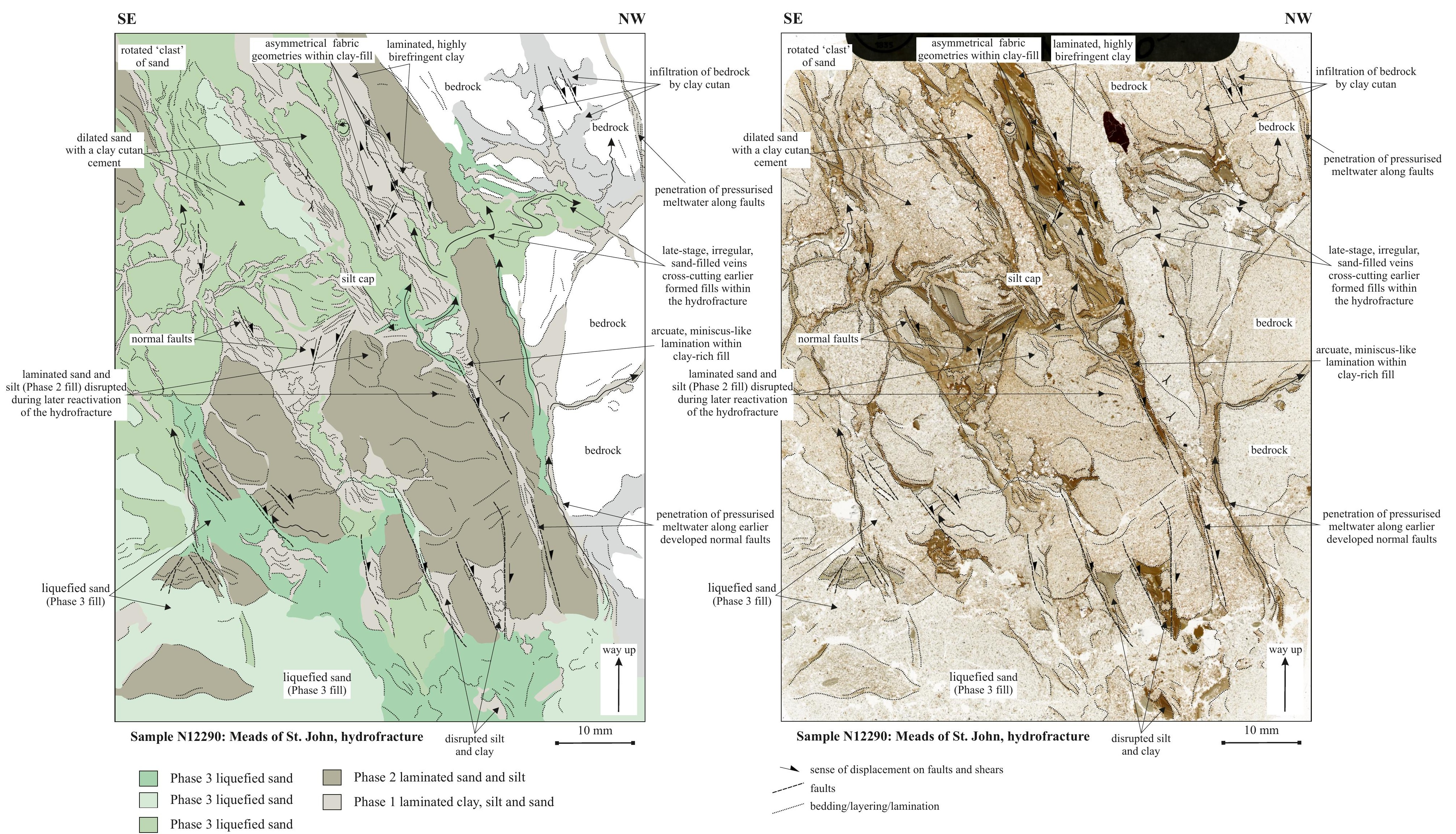

Figure 15 


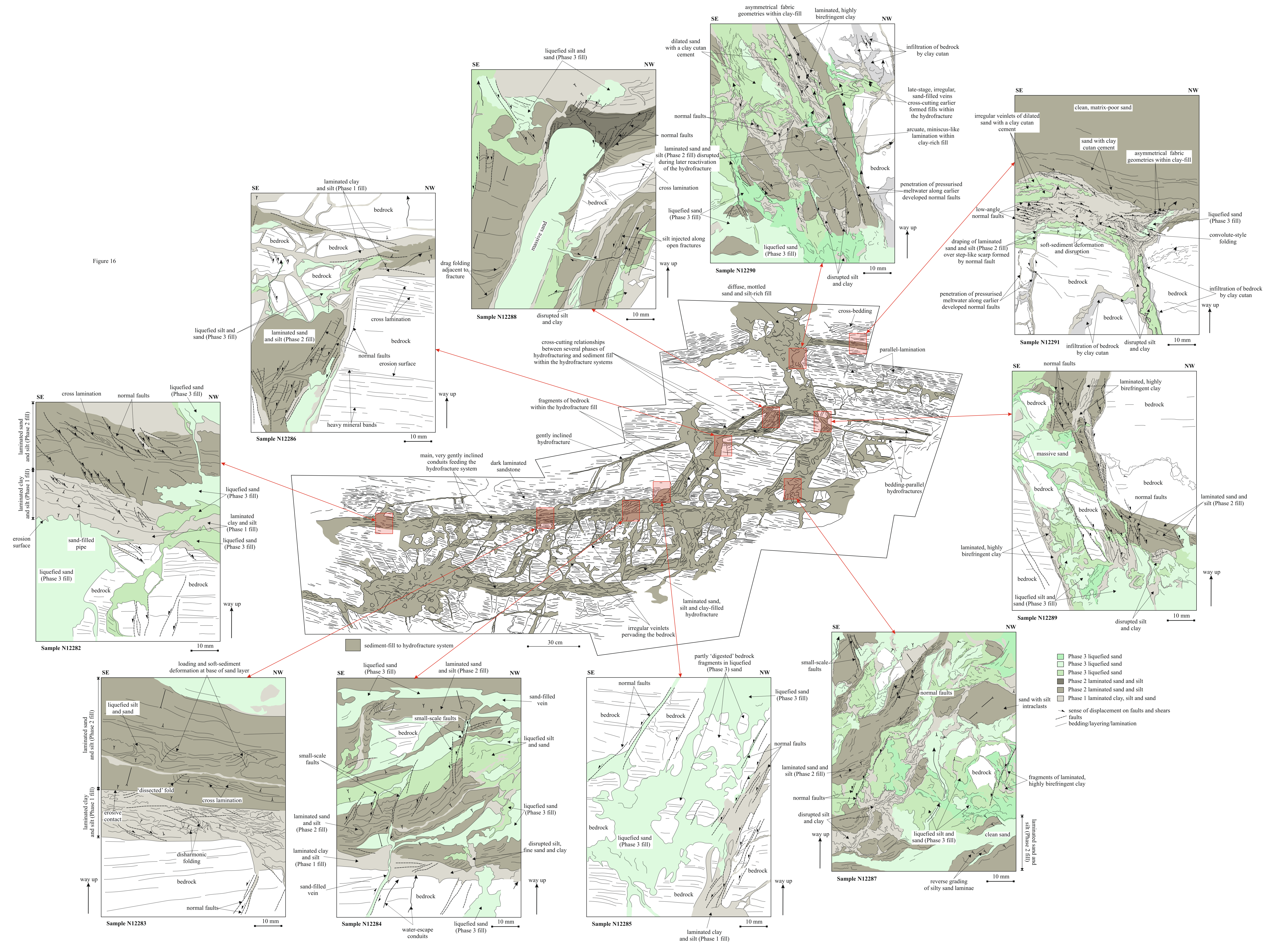




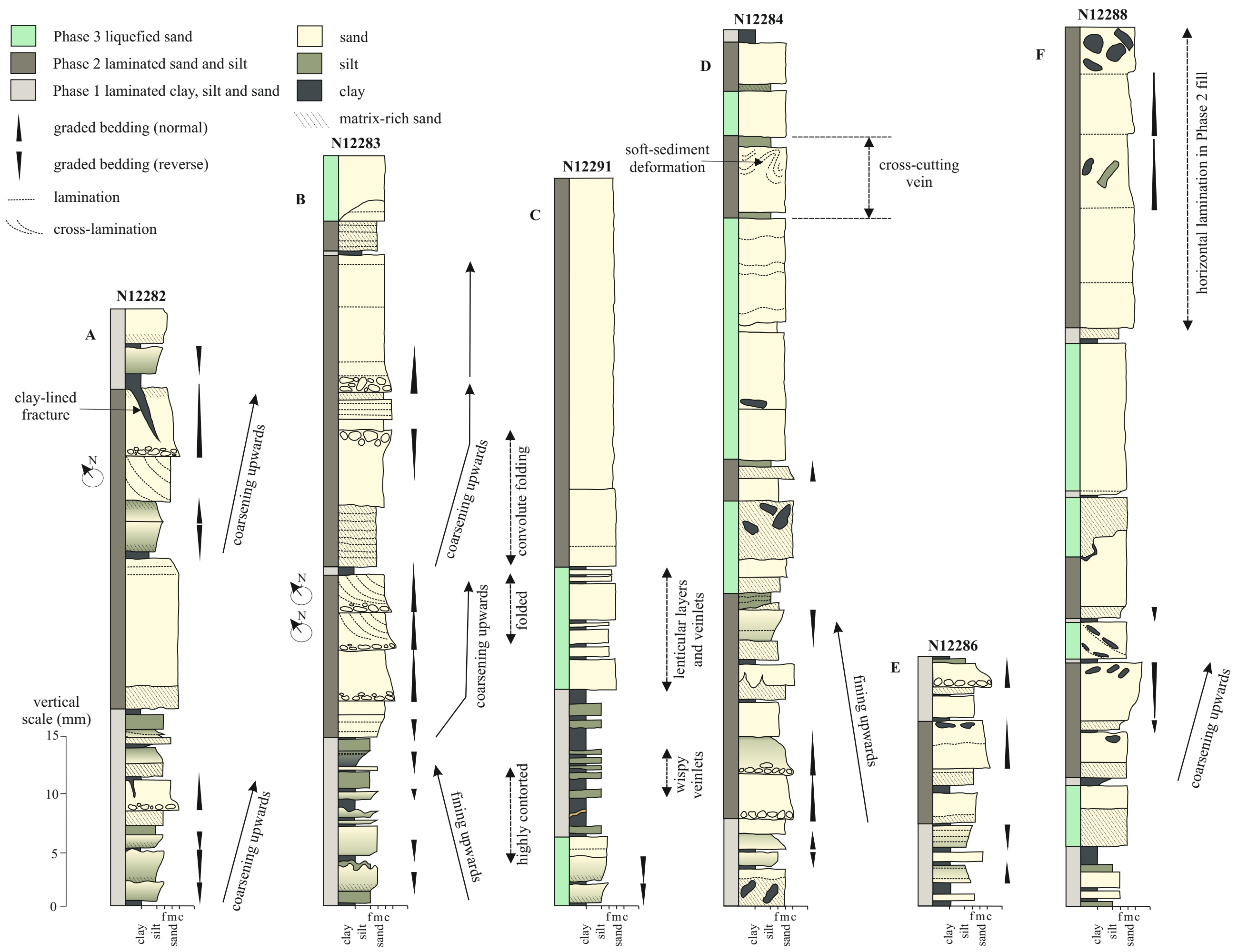




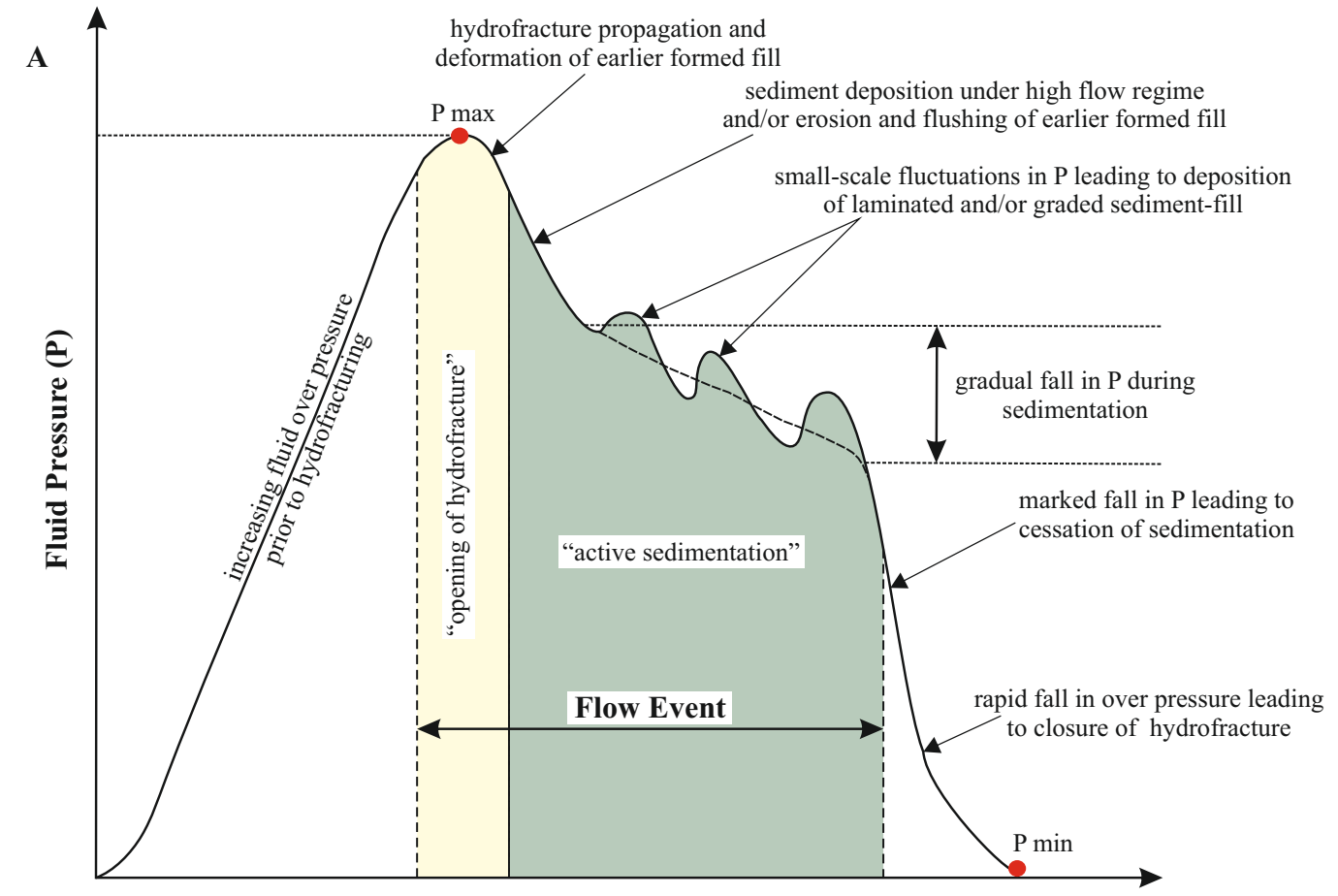

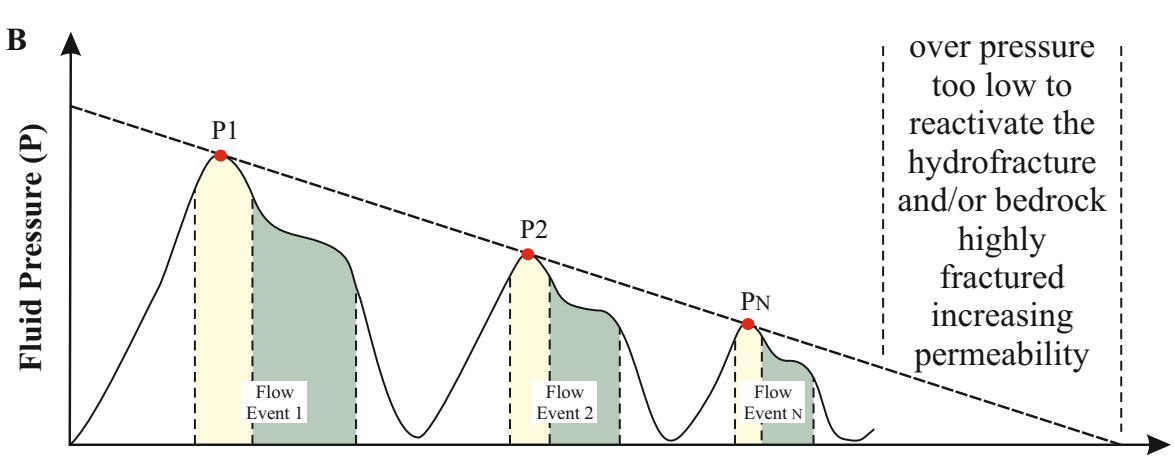

Time (T)

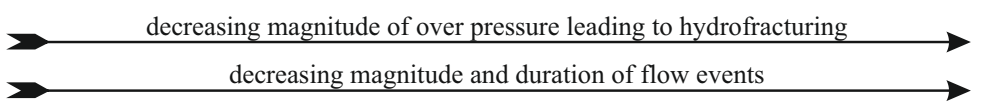

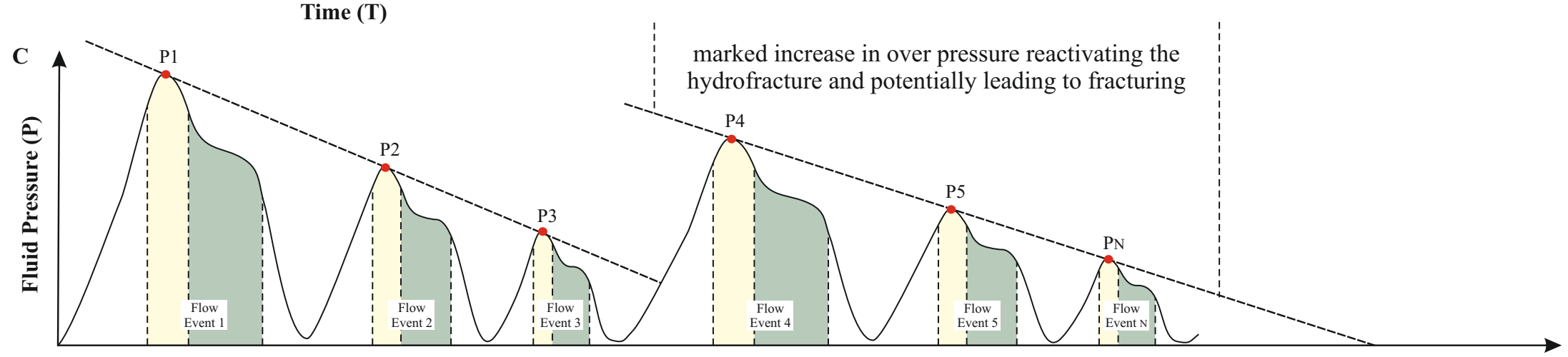

Time (T) 

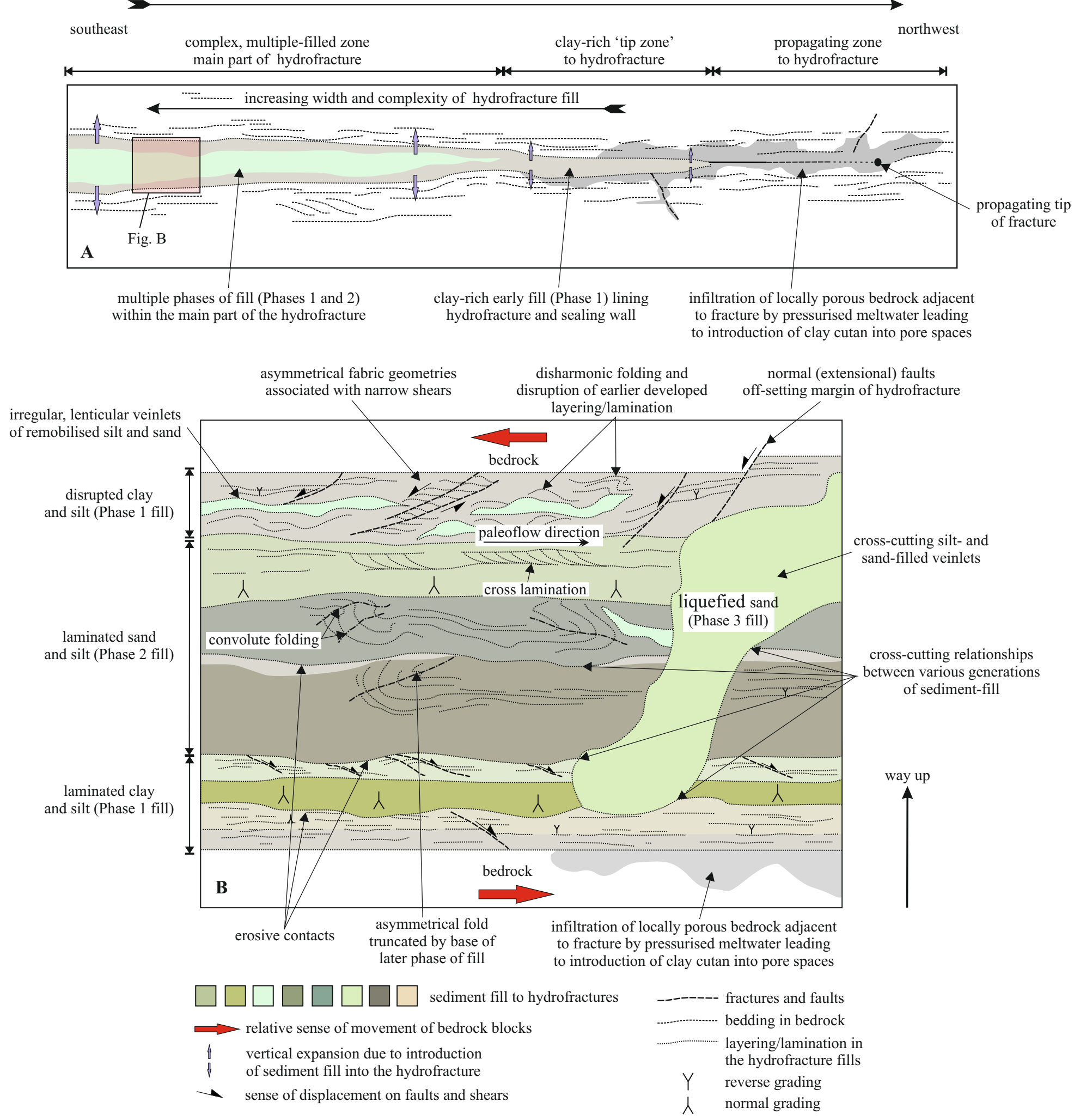
A

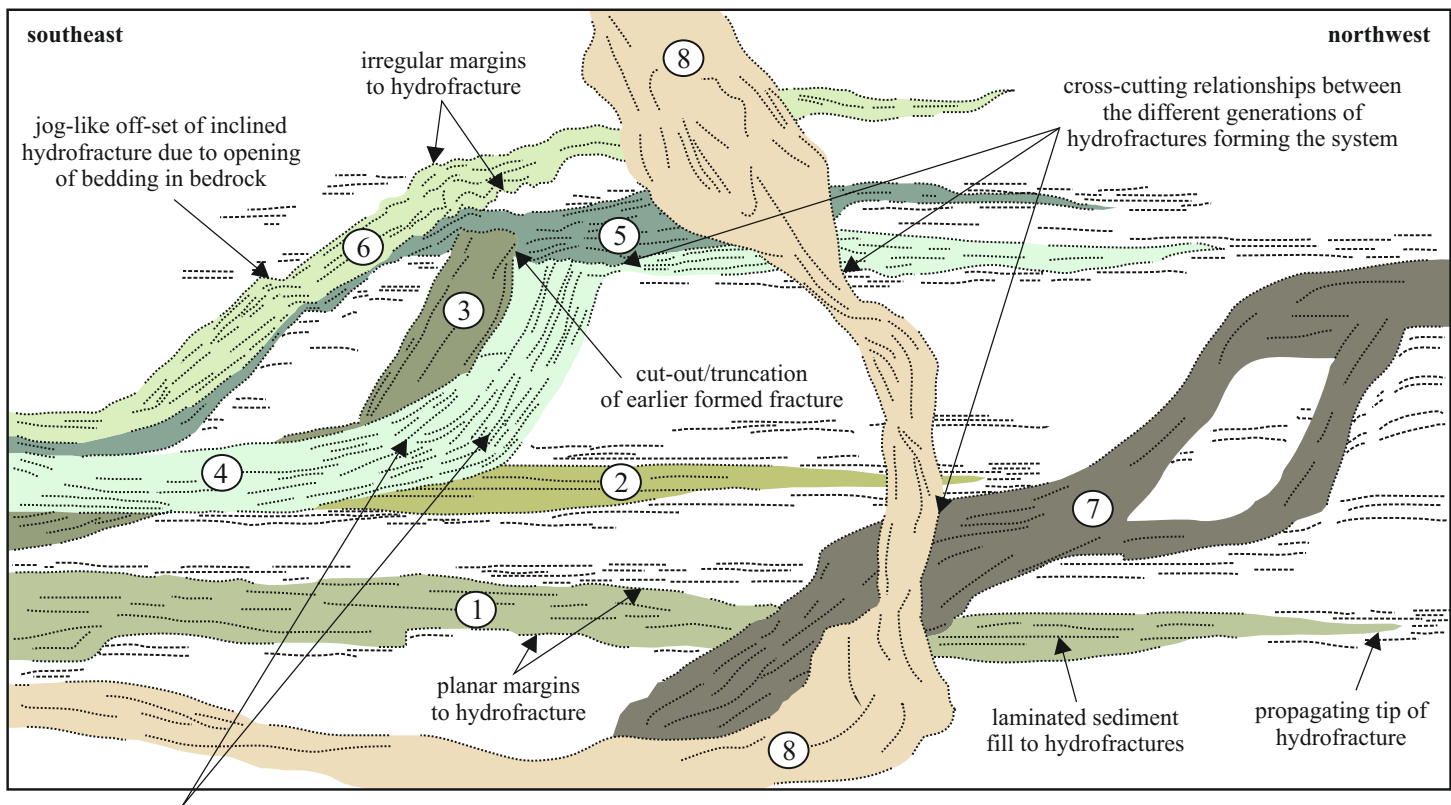

cross-cutting relationships

between the different stages

fill within the of hydrofracture
(1) to (8) relative age of the different parts of the hydrofracture system (1 - oldest; 8 - youngest)

overall propagation direction of the hydrofracture

by cessation of forward propagation of the system

bedrock undergoing extension during hydrofracturing

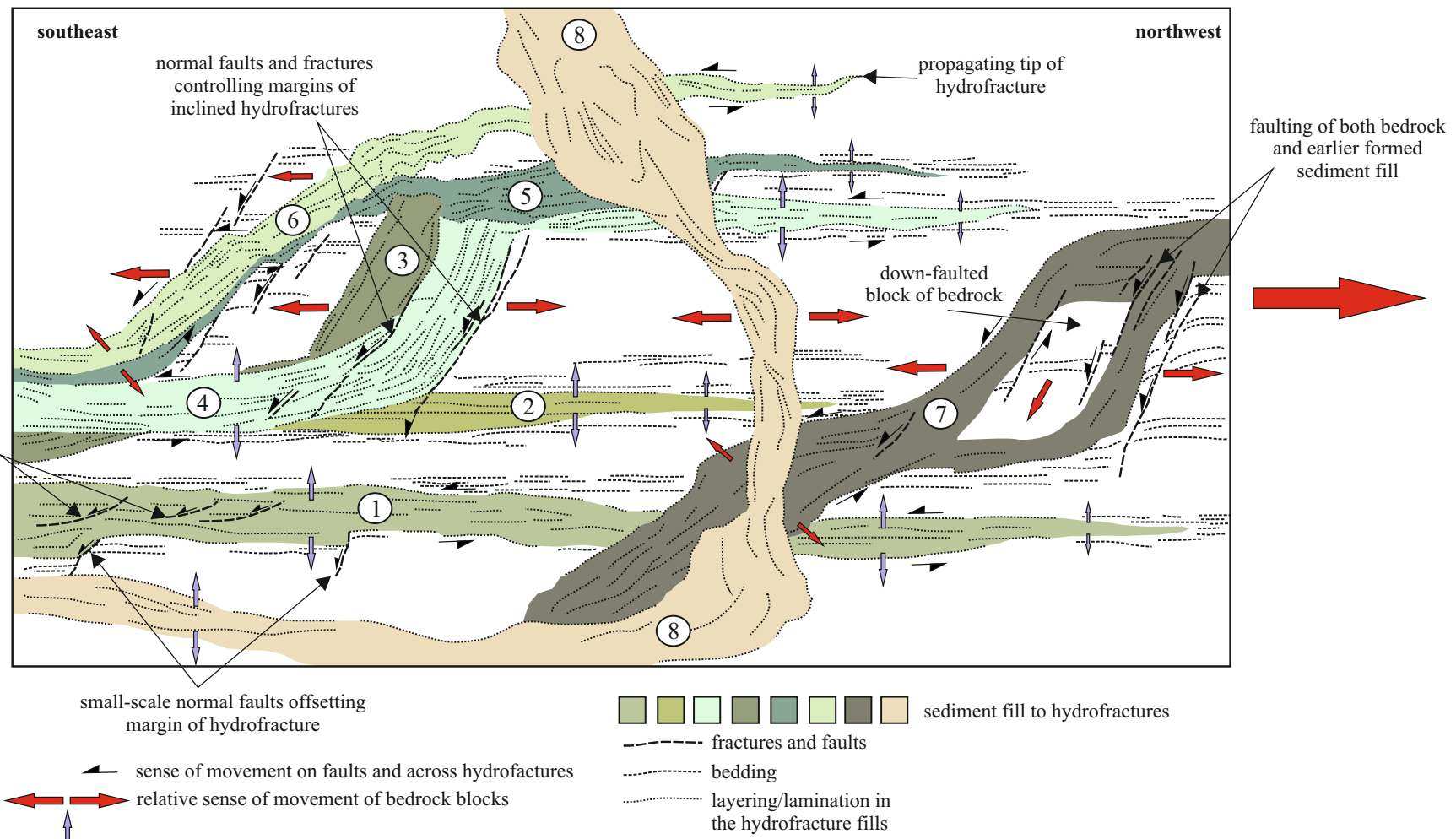
the hydrofracture fills

low-angle extensional faults deforming layering within the hydrofracture fill

vertical expansion due to introduction of sediment

\ fill in bedding-parallel hydrofractures 
southeast

northwest

A Event 1 - injection of hydrofracture 1 parallel to bedding

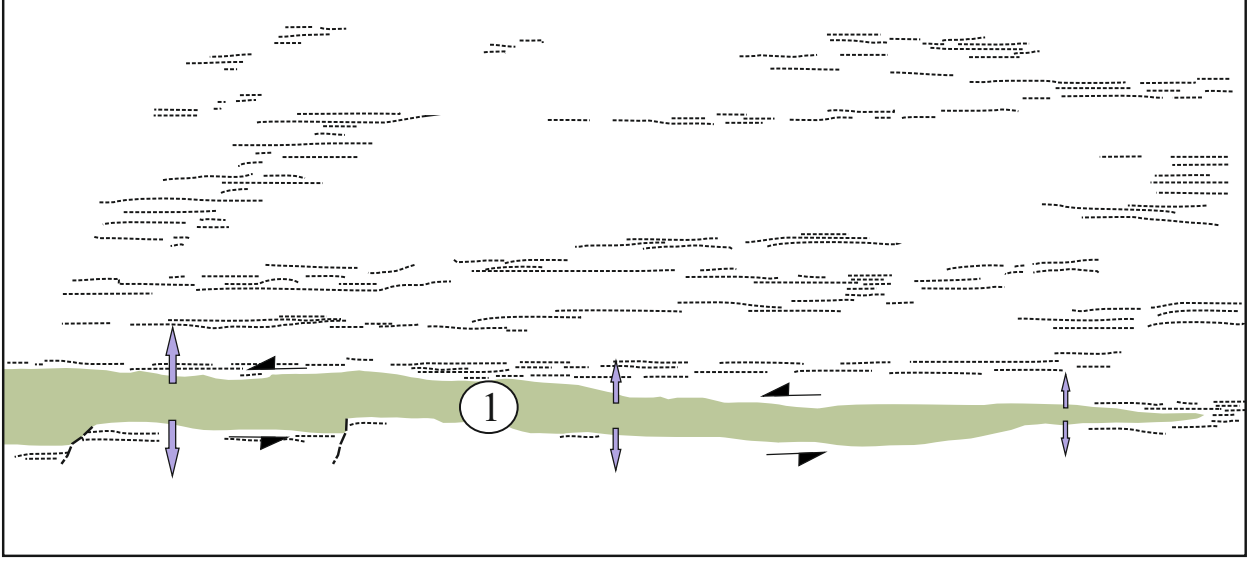

C

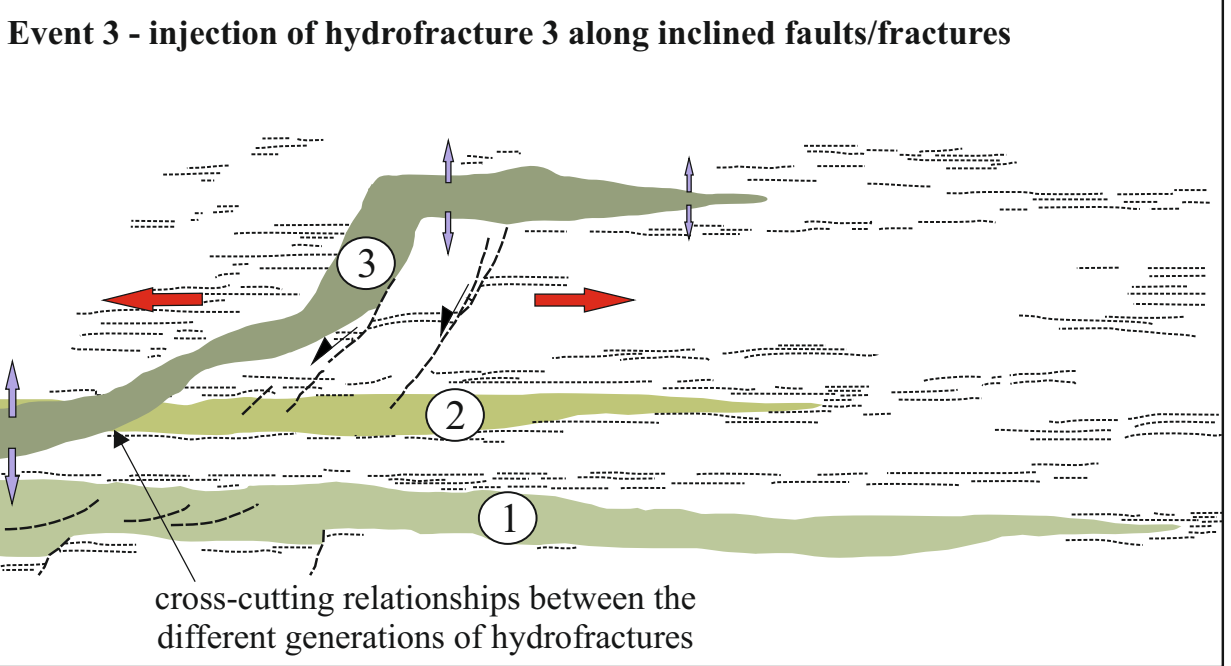

$\mathbf{E}$

Event 5 - injection of hydrofracture 5 during a slight shift in the focus of brittle deformation

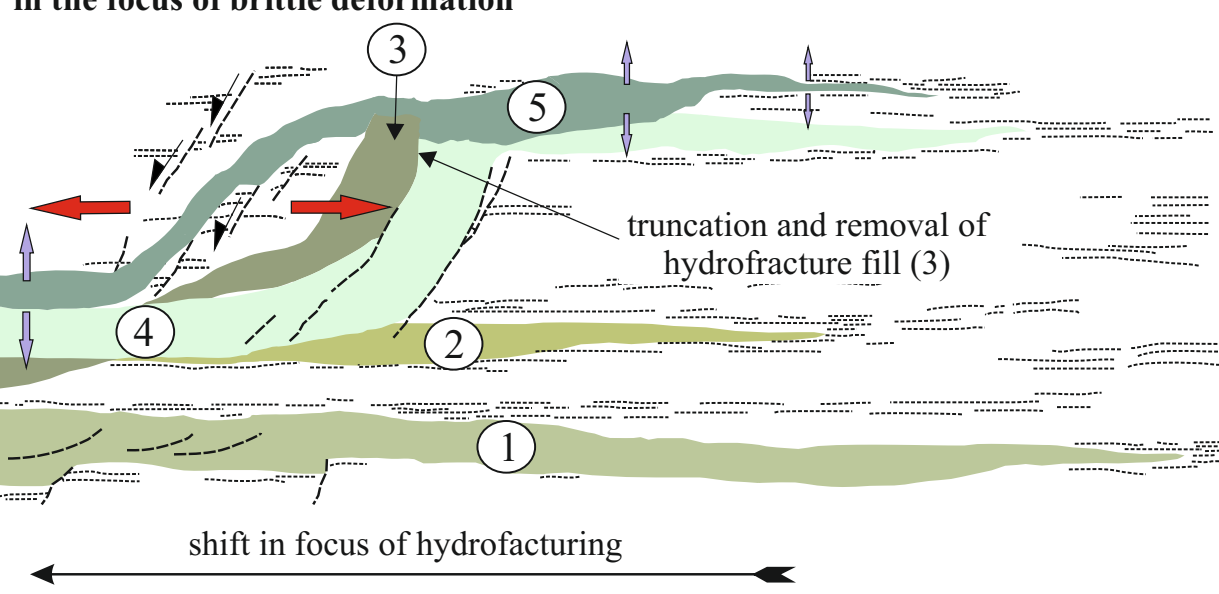

G Event 7 - injection hydrofracture 7 accompanied by brittle faulting and down-faulting of bedrock fragments within this hydrofracture

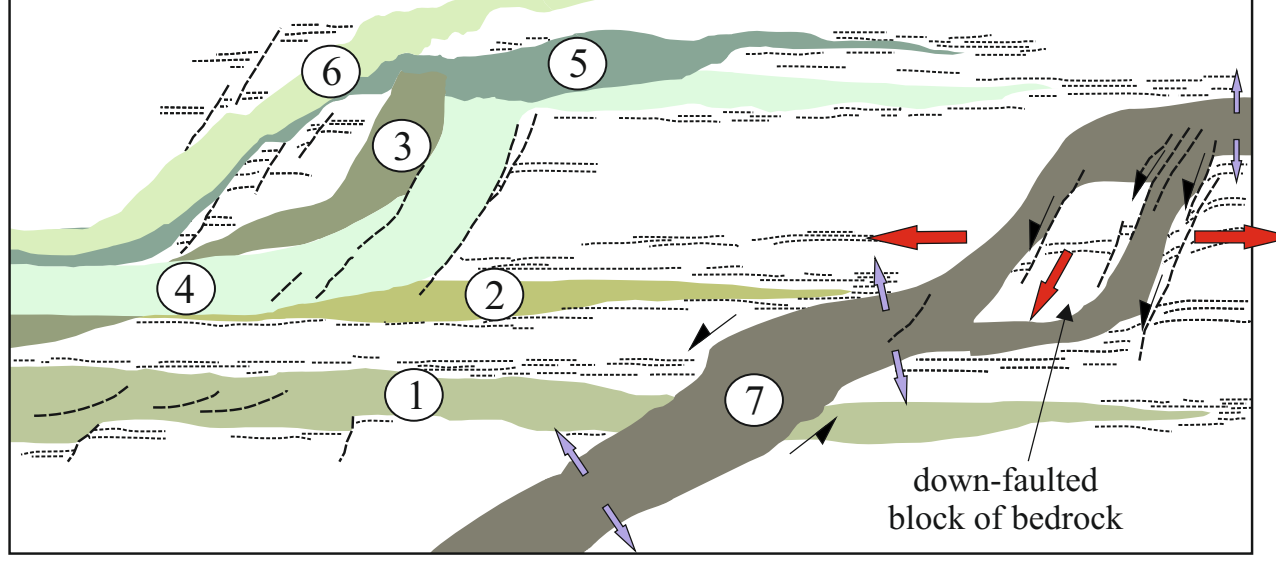

southeast

northwest

B

Event 2 - injection of hydrofracture 2 parallel to bedding

$\ldots \ldots$

........

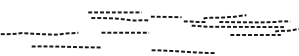

possible faulting of earlier hydrofracture

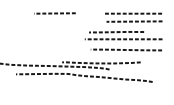

$\therefore-1$.

(2) 10

Event 4 - injection of hydrofracture 4 along inclined faults/fractures during continued brittle deformation
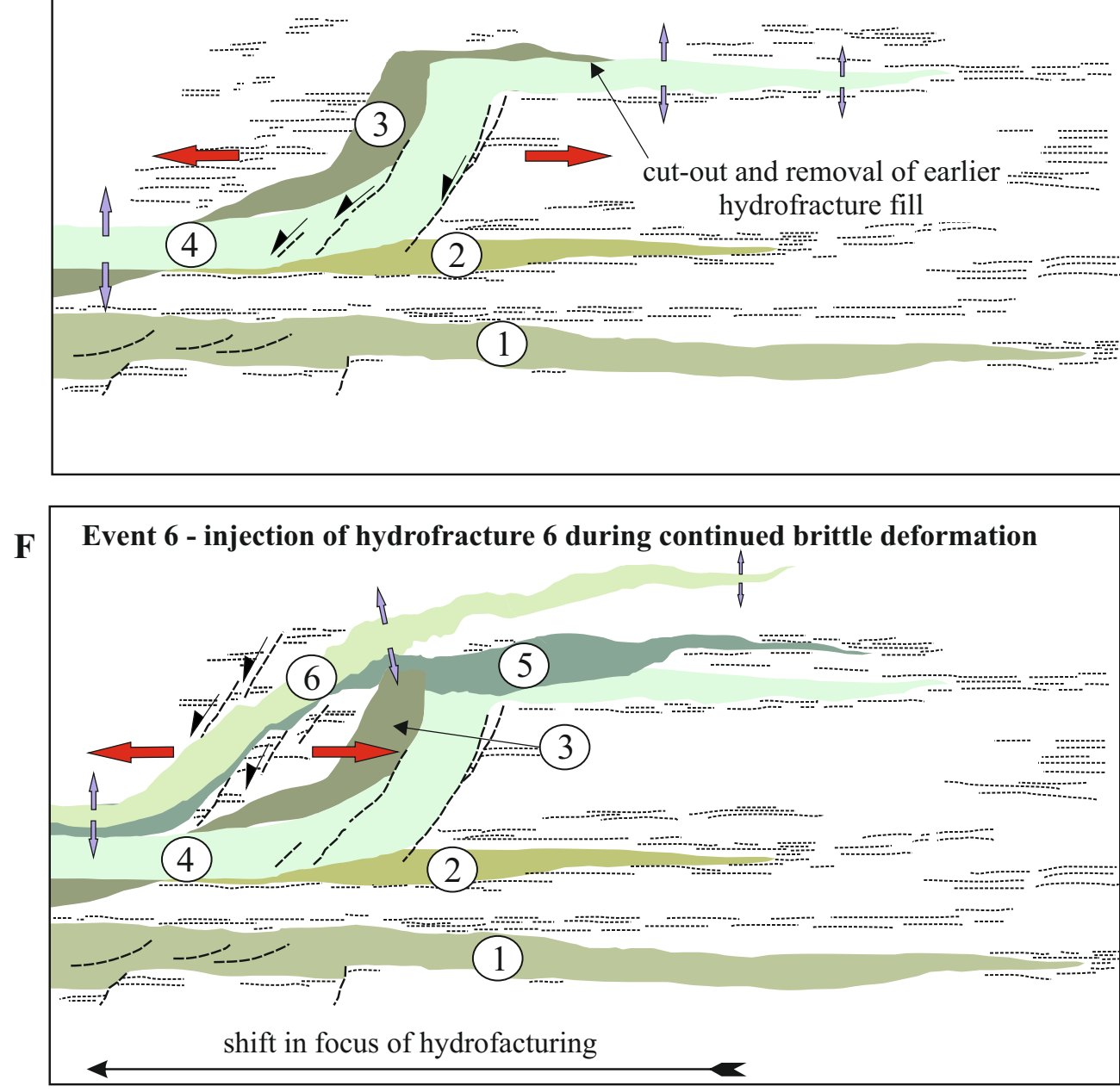

H Event 8 - injection of hydrofracture 8 cross-cutting all of the earlier phases within the system $\longleftrightarrow$ 8 $\Rightarrow$

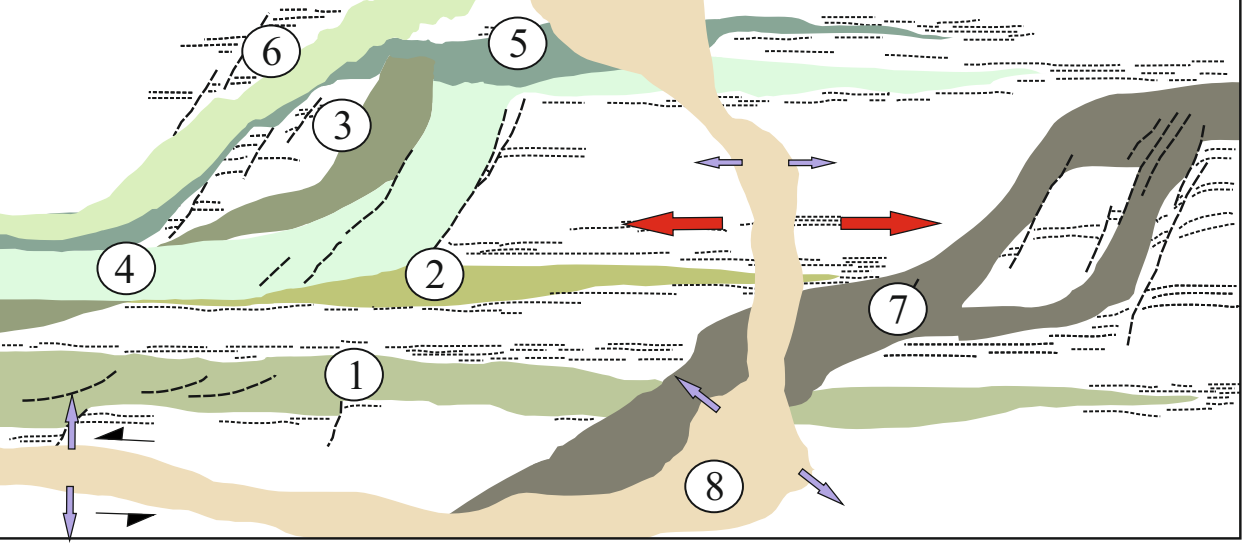


A. subglacial hydrofracture development (Events 1 and 2)

hydrofractures propagating along preexisting

plane of weakness in bedrock

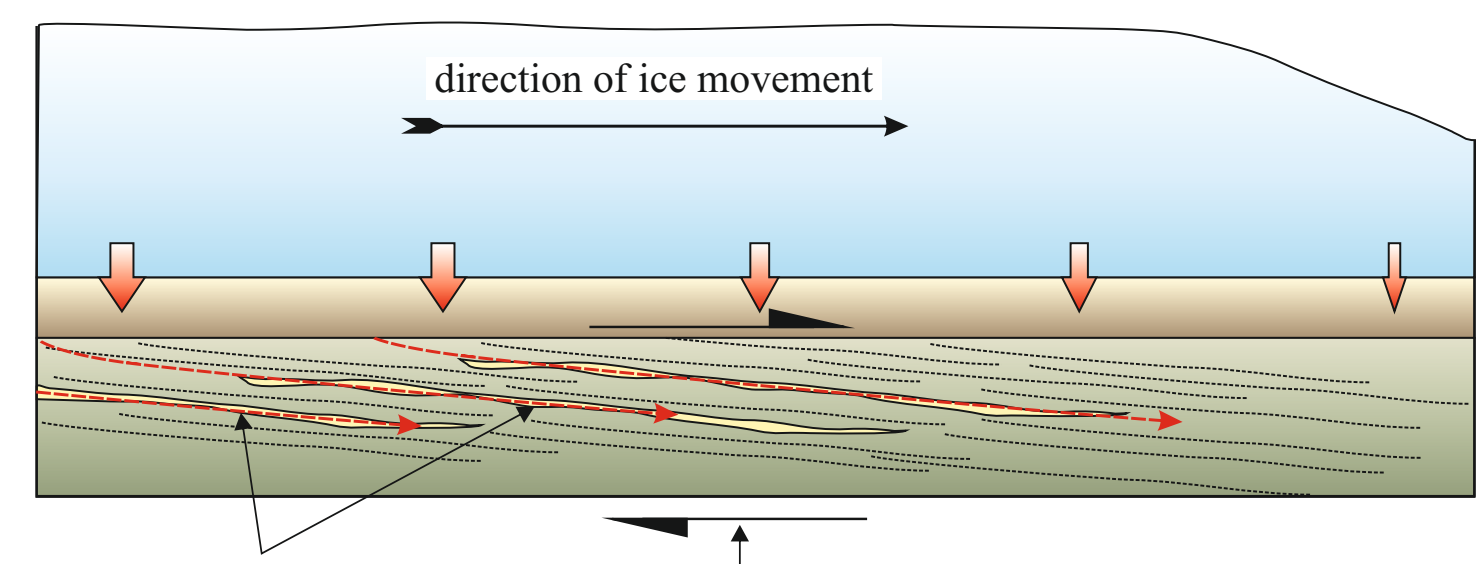

developing hydrofractures

dip down-ice

simple shear deformation

imposed by overriding ice

hydrostatic gradient resulting in flow of pressurised meltwater towards the ice margin

B. submarginal hydrofracture development (Events 3 to 6)

orientation of hydrofractures influenced

by decreasing thickness of ice towards

the glacier margin

retreating ice margin
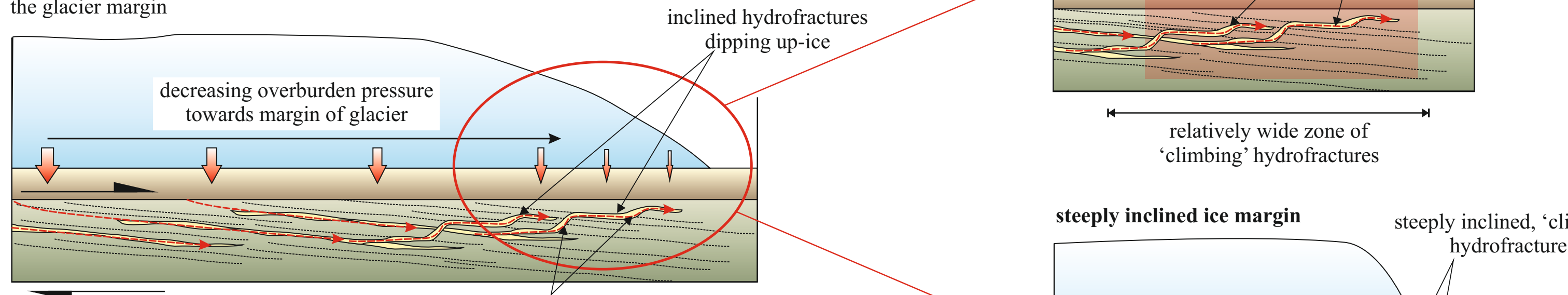

hydrofractures 'climbing'

upwards due to decreasing overburden

pressure towards ice margin

C. ice marginal hydrofracture development (Events 7 and 8)

irregular cross-cutting hydrofractures developed at the

ice-margin due to a marked decrease in overburden

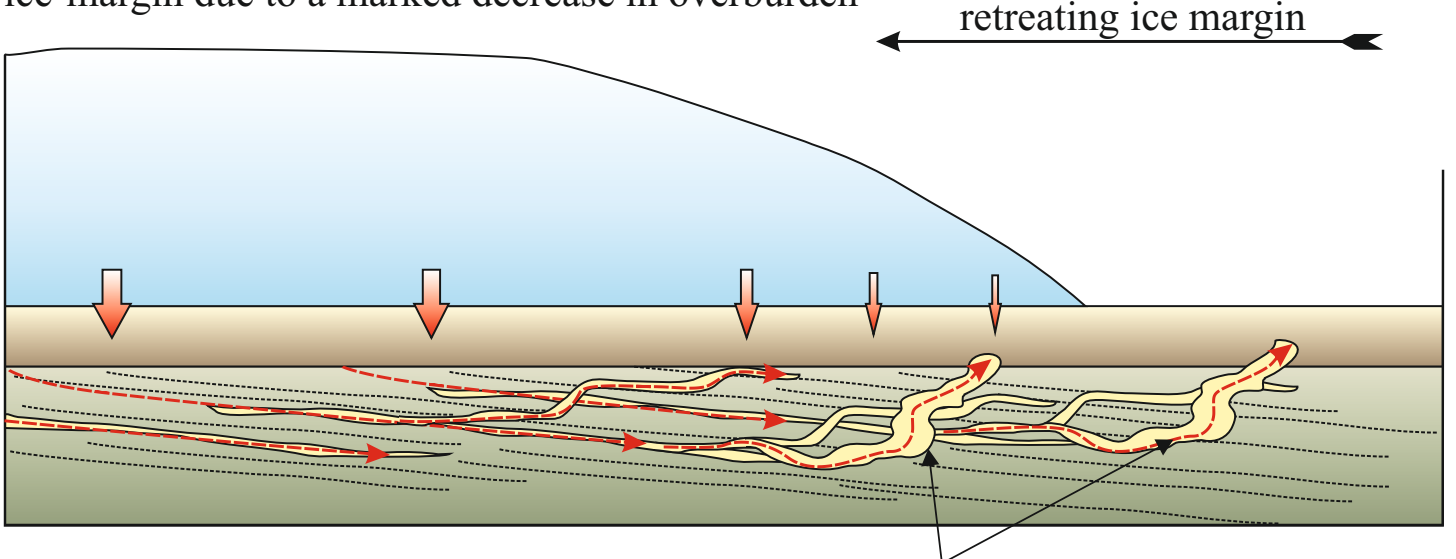

steeply inclined ice margin $\quad$ steeply inclined, 'climbing'

irregular, steeply inclined, cross-cutting hydrofracture 'climbing' rapidly upwards due to the marked decrease in overburden at the ice margin 